\title{
Ethanol-extracted Cameroonian propolis exerts estrogenic effects and alleviates hot flushes in ovariectomized Wistar rats
}

Stéphane Zingue ${ }^{1,2^{*}}$, Chantal Beatrice Magne Nde ${ }^{3}$, Thomas Michel ${ }^{4}$, Derek Tantoh Ndinteh ${ }^{5}$, Jules Tchatchou ${ }^{2}$, Moïse Adamou ${ }^{6}$, Xavier Fernandez ${ }^{4}$, Fernand-Nestor Tchuenguem Fohouo ${ }^{6}$, Colin Clyne ${ }^{3}$ and Dieudonné Njamen ${ }^{2,5^{*}}$

\begin{abstract}
Background: Since the biological properties of propolis depend to the plants that can be found in a specific region, propolis from unexplored regions attracts the attention of scientists. Ethanolic extract of Cameroonian propolis (EEP) is used to treat various ailments including gynecological problems and amenorrhea. Since there were no scientific data to support the above claims, the present study was therefore undertaken to assess estrogenic properties of Cameroonian propolis.
\end{abstract}

Methods: To achieve our goal, the ability of EEP to induce MCF-7 cells proliferation in E-screen assay as well as to activate estrogen receptors $a(E R a)$ and $\beta(E R \beta)$ in cell-based reporter gene assays using human embryonic kidney cells (HEK293T) transfected with ERs was tested. Further, a 3-day uterotrophic assay was performed and the ability of EEP to alleviate hot flushes in ovariectomized adult rats was evaluated.

Results: In vitro, EEP showed an antiestrogenic activity in both HEK293T ER- $a$ and ER- $\beta$ cells. In vivo, EEP induced a significant increase in a bell shape dose response manner of the uterine wet weight, the total protein levels in the uterus, the uterine and vaginal epithelium height and acini border cells of mammary gland with the presence of abundant eosinophil secretions. Moreover, EEP induced a significant decrease in the total number, average duration as well as frequency of hot flushes after 3 days of treatment in rat (equivalent to a month in woman). The dose of $150 \mathrm{mg} / \mathrm{kg}$ exhibited the most potent estrogenic effects among all the tested doses. The UPLC-HRMS analysis showed the presence of caffeic acid derivatives and trirtepernoids in EEP, which are well known endowed with estrogenic properties.

Conclusion: These results suggest that Ethanolic extract of Cameroonian propolis has estrogen-like effects in vivo and may alleviate some menopausal problems such as vaginal dryness and hot flushes.

Keywords: Cameroonian propolis, Ethanolic extract of propolis, Phytoestrogens, Hot flushes, Ovariectomized rat, E-screen assay

\footnotetext{
*Correspondence: stephanezingue@gmail.com; dnjamen@gmail.com

'Laboratory of Physiology and Natural Products Research, Department of Life

and Earth Sciences, Higher Teachers' Training College, University of Maroua,

P.O. Box 55, Maroua, Cameroon

${ }^{2}$ Laboratory of Animal Physiology, Department of Animal Biology and

Physiology, Faculty of Science, University of Yaounde 1, P.O. Box 812,

Yaoundé, Cameroon

Full list of author information is available at the end of the article
}

(c) The Author(s). 2017 Open Access This article is distributed under the terms of the Creative Commons Attribution 4.0 International License (http://creativecommons.org/licenses/by/4.0/), which permits unrestricted use, distribution, and reproduction in any medium, provided you give appropriate credit to the original author(s) and the source, provide a link to the Creative Commons license, and indicate if changes were made. The Creative Commons Public Domain Dedication waiver (http://creativecommons.org/publicdomain/zero/1.0/) applies to the data made available in this article, unless otherwise stated. 


\section{Background}

Hot flushes are the most disturbing and annoying symptom associated with natural menopause or following oophorectomy [1]. Also known as vasomotor symptoms, it occurs in $80 \%$ of menopausal women [2]. Hot flush is characterized by a sudden sensation of heat or burning starting in the head or neck and passing over the entire body. Hot flushes are not life-threatening but can negatively affect life's quality for many women by causing sleep disturbances that often result in fatigue, irritability, forgetfulness, and acute physical discomfort, with negative effects on daily activities and work [3]. In addition, hot flushes may be associated with serious medical conditions. Women with hot flushes may have an increased risk of developing Alzheimer's disease, a serious neurodegenerative disease, compared to women without hot flushes [4]. Hormone Replacement Therapy (HRT) was for a long time the treatment of choice for the management of climacteric problems [5]. Although estrogen therapy is effective in suppressing hot flushes, it is associated with an increased risk of endometrial cancer, and when combined with a progestin to prevent endometrial hyperplasia, it increases long-term risk of cardiovascular, cerebrovascular, and thromboembolic events [6]. This has resulted in a search for HRT alternatives, and plantderived substances, so-called phytoestrogens have received a great deal of attention due to its potential protective effects against cardiovascular diseases, osteoporosis and hormone-dependent cancers [7, 8]. These compounds are flavonoids, lignanes, chalcone, coumestane and erythroidine alkaloids $[9,10]$ and are being increasingly promoted as the safer "natural alternative" to HRT [11].

Propolis is a popular remedy in the folk medicine of several countries and a raw material for numerous preparations, health foods and beverages [12]. It is a strongly adhesive natural mixture produced by honeybees (Apis mellifera) from resin collected on buds, leaves and stem barks of some plants, mixed with pollen as well as enzymes secreted from the saliva glands of bees [12-14]. Nowadays, more than 300 compounds, among which flavonoids, terpenoids, steroids, sugars, vitamins and amino acids have been detected in raw propolis and many valuable biological activities have been attributed to propolis $[15,16]$. Varied properties of propolis have contributed to its wide use in traditional medical practice and for commercial purposes [12, 13, 17]. Since the biological properties of propolis depend on its chemical composition which greatly varies according to the plants that can be found in a specific region [13, 18, 19], propolis from unexplored regions attracts the attention of scientists in the search of new bioactive molecules [12]. The use of propolis in the treatment and prevention of numerous diseases has been documented [20]. In Cameroon, a natural product prepared as ethanolic extract of propolis is used to treat wounds, burns respiratory and dental infections, stomach ulcer, diabetes, high blood pressure as well as amenorrhea and gynecological problems [21-23]. Although EEP is being used increasingly in Cameroonian traditional system, there are many of its pharmacological activities claimed that remain unproven. The available data on the characteristics of Cameroonian propolis were the work of Mbawala et al. [21, 24] and Seidel et al. [25] on the antimicrobial activities of the ethanol extracts from two different regions (see Table 1). Njintang et al. [23] reported the antiradical activities of Cameroonian propolis. Moreover, there are two reports concerning compounds isolated from Cameroonian propolis [26, 27]. However, there have not yet been reports on estrogenic potential of Cameroonian propolis. In the present study, estrogenic effects of Cameroonian propolis sample collected from Meiganga locality of Adamawa Region of Cameroon were assessed in vitro in E-screen and cell-based reporter gene assays. In vivo, a 3-day uterotrophic assay in ovariectomized adult rats (a classical tool for the detection of estrogenicity of chemicals) was used. Furthermore, its ability to alleviate hot flushes induced in ovariectomized rats was assessed.

\section{Methods}

\section{Chemicals and reagents}

Mass Spectroscopy (MS) grade methanol, acetonitrile (ACN), water and formic acid (FA) for UPLC-MS analyses were purchased from Sigma-Aldrich (Saint-Quentin Fallavier, France). Estradiol valerate (Progynova $2 \mathrm{mg}$ ) was purchased from DELPHARM (Lille, France). Genistein was obtained from "Extrasynthese" (Genay, France). The penicilline (xtapen ${ }^{\circ}$ ) was provided by CSPC Zhongnuo pharmaceutical (Shijiazhuang City, China). The Diclofenac $\left(\right.$ Dicloecnu $\left.^{\circ}\right)$ was provided by ECNU pharmaceutical (Yanzhou City, China). Serums and antibiotics were purchased from GIBCO (Grand Island, NY). The $17 \beta$-estradiol benzoate [(Estr-1,3,5(10)-trien-3,16 $\alpha, 17 \beta$ triol); purity $\geq 98 \%$ ] was obtained from Sigma-Aldrich (Hamburg, Germany). The 2-[4-(2-hydroxyethyl)piperazin-1-yl] ethane sulfonic acid (HEPES, purity $\geq 99.5 \%$ ) was purchased from Ludwig Biotecnologia Ltda (Alvorada, RS, Brazil). Trypan blue, Alamar blue, Sulforodamine B and cell culture mediums were purchased from Sigma-Aldrich (St. Louis, MO, USA). The Smart Button Data loggers were purchased from ACR System Inc (Surrey, Canada).

\section{Source and preparation of Cameroonian propolis}

The propolis used in this study was harvested in Meiganga locality of Adamawa Region in January 2013. The ethanolic extract of propolis was prepared as previously described by Mbawala et al. [21] and Njintang et al. [23] and stored under dry conditions at $4{ }^{\circ} \mathrm{C}$ until needed for 
Table 1 Recapitulative informations on propolis from Adamawa Region, Cameroon

\begin{tabular}{|c|c|c|c|c|}
\hline Propolis samples (Year) & Solvant of extraction (Yield) & Phytochemical constituent & Biological activities & Reference \\
\hline $\begin{array}{l}\text { Propolis Meiganga } \\
(2003 \text { \& 2005) }\end{array}$ & Ethanol (3.27\%) & $\begin{array}{l}\text { Detection of phenolic compounds } \\
\text { with HPLC-PDA }\end{array}$ & $\begin{array}{l}\text { Antibacterial activity against gram } \\
\text { positive bacteria. Relation between } \\
\text { phenolic compounds amount and } \\
\text { antibacterial activity. }\end{array}$ & {$[21,24]$} \\
\hline $\begin{array}{l}\text { Propolis Meiganga } \\
\text { (2006) }\end{array}$ & Methanol (3.7\%) & $\begin{array}{l}\text { lup-20(29)-en-3-one, lupeol, } \\
\text { erythrodiol palmitate, 18-iso-olean- } \\
\text { 12-ene-3,11-dione, Caffeic acid } \\
\text { phenethyl ester (CAPE) }\end{array}$ & $\begin{array}{l}\text { Antinociceptive activity of all the } \\
\text { three pentacyclic triterpenoids in the } \\
\text { test models of chemical nociception } \\
\text { and mechanical hypernociception }\end{array}$ & {$[26]$} \\
\hline $\begin{array}{l}\text { Propolis Meiganga } \\
\text { (2008) }\end{array}$ & Hexane (44.8\%) & $\begin{array}{l}\text { Alkaloids, Coumarins, Steroids, } \\
\text { Triterpenes, Volatile, } 2 \text { compound } \\
\text { was not yet elucidated }\end{array}$ & Absence of antibacterial activity & {$[27]$} \\
\hline $\begin{array}{l}\text { Propolis Meiganga } \\
\text { (2008) }\end{array}$ & Methanol (3.5\%) & $\begin{array}{l}\text { Alkaloids, Reducing compounds, } \\
\text { Coumarins, Flavonoids, Saponins, } \\
\text { Tannins }\end{array}$ & $\begin{array}{l}\text { Antibacterial activities; It was active } \\
\text { against Escherichia coli and } \\
\text { Pseudomonas aeruginosa } \\
\text { (MIC: } 0.2 \mathrm{mg} / \mathrm{ml} \text { ) }\end{array}$ & {$[27]$} \\
\hline $\begin{array}{l}\text { Propolis Adamawa } \\
\text { (2013) }\end{array}$ & $\begin{array}{l}\text { Acetone and } \\
\text { methanol (70\%) }\end{array}$ & $\begin{array}{l}\text { Terpenoids, phenolic acids, ursolic } \\
\text { acid, } \beta \text {-amyrin, Prenylated } \\
\text { phloroglucinone, cycloartenol } \\
\text { acetate }\end{array}$ & $\begin{array}{l}\text { Phlorogucinonone was found to } \\
\text { possess the highest potency against } \\
\text { Trypanosoma brucei brucei }\end{array}$ & {$[52]$} \\
\hline $\begin{array}{l}\text { Propolis Adamawa } \\
\text { (2007) }\end{array}$ & Ethanol (missing data) & Missing data & $\begin{array}{l}\text { Among all African propolis sample } \\
\text { tested, Cameroonian propolis was the } \\
\text { most potent. }\end{array}$ & {$[25]$} \\
\hline $\begin{array}{l}\text { Propolis Ngaoundal } \\
\text { (2011) }\end{array}$ & $\begin{array}{l}\text { Ethanol }(5.25 \%) \text {, methanol } \\
\text { (9\%) and water (1.5\%) }\end{array}$ & $\begin{array}{l}\text { Volatile oils, Phenolic compounds, } \\
\text { Saponins, Reducing substances, } \\
\text { Coumarines, Flavonoids, Triterpenes, } \\
\text { Catechic tannins, Fatty acids. }\end{array}$ & $\begin{array}{l}\text { All extracts contain phenolic } \\
\text { compounds and present antiradical } \\
\text { activities Antioxidant capacities: the } \\
\text { order of decreasing antiradical activity } \\
\text { is Water > Methanol > Ethanol }\end{array}$ & {$[26]$} \\
\hline $\begin{array}{l}\text { Propolis } \\
\text { Ngaoundere (2004) }\end{array}$ & Ethanol (missing data) & $\begin{array}{l}\text { Total polyphenols (mg/L) } 10.99 \pm 2.56 \\
\text { Tannins (mg/L): } 1.57 \pm 1.62\end{array}$ & $\begin{array}{l}\text { The Cameroonians propolis exhibited } \\
\text { higher scavenging (antiradical activity } \\
(\%): 83.4 \pm 2.3 \text { ); activity which could } \\
\text { justify their commercialisation and role } \\
\text { in the management of some chronic } \\
\text { diseases }\end{array}$ & {$[23]$} \\
\hline $\begin{array}{l}\text { Propolis } \\
\text { Ngaoundere (2003) }\end{array}$ & Ethanol (missing data) & $\begin{array}{l}\text { Total polyphenols (mg/L) } 227.8 \pm 36.0 \text {; } \\
\text { Tannins (mg/L): } 16.3 \pm 12.6 \\
\text { (PROMAX-C, 2003) } \\
\text { Total polyphenols (mg/L) } 772.8 \pm 270.2 \\
\text { Tannins (mg/L): } 453.8 \pm 361.5 \text { in } \\
\text { PROMAX-C of } 2006\end{array}$ & $\begin{array}{l}\text { All PROMAX-C samples tested showed } \\
\text { evidence of radical scavenging properties } \\
\text { with values ranging from } 28 \text { to } 70 \% \text {. } \\
\text { Radical scavenging activity: Antiradical } \\
\text { activity (\%): } 43.7 \pm 13.8 \text { for PROMAX-C } \\
\text { made in } 2003 \text { and Antiradical activity } \\
\text { (\%): } 67.3 \pm 3.0 \text { for PROMAX-C made } \\
\text { in } 2006 .\end{array}$ & [23] \\
\hline $\begin{array}{l}\text { Propolis } \\
\text { Meiganga (2005) }\end{array}$ & Ethanol (4\%) & Contains phenolic compounds & $\begin{array}{l}\text { Antibacterial activity against gram positive } \\
\text { bacterial strain tested except Enterococcus } \\
\text { faecalis }\end{array}$ & {$[21]$} \\
\hline $\begin{array}{l}\text { Propolis } \\
\text { Martap (2005) }\end{array}$ & Ethanol (3.5\%) & $\begin{array}{l}\text { Most active than PROMAX-C from } \\
\text { Meiganga with a most higher } \\
\text { phenolic content }\end{array}$ & $\begin{array}{l}\text { Antibacterial activity against gram positive } \\
\text { bacterial strain tested except Enterococcus } \\
\text { faecalis. This propolis was the most active } \\
\text { and content more phenolic compounds } \\
\text { than other tested propolis. }\end{array}$ & {$[21]$} \\
\hline
\end{tabular}

analysis. Briefly, after drying and grinding, $62.5 \mathrm{~g}$ of dried propolis were extracted with $150 \mathrm{~mL}$ of ethanol $70 \%(\mathrm{v} / \mathrm{v})$ at room temperature for $24 \mathrm{~h}$. The ethanol suspension was separate by centrifugation at $1000 \mathrm{rpm}$ for $10 \mathrm{~min}$ at room temperature, and the supernatant was poured in a $50 \mathrm{~mL}$ dark volumetric flask and the volume completed with $70 \%$ ethanol. To achieve our experimental goal, $0.5 \mathrm{~L}$ of EEP was lyophilized during $72 \mathrm{~h}$ (Christ Beta 1-8 K, Bioblock scientific, Germany) to yield 20.22 g of a brown powder. The extracts were stored under dry conditions at $4{ }^{\circ} \mathrm{C}$ until needed for analysis.

\section{Determination of doses}

The doses of administration were calculated based on the posology prescribed for gynecological complaints and amenorrhea: 2 tea spoons in $1 / 2$ of glass water, 3 times a day. This was powdered by lyophilisation to afford $0.4 \mathrm{~g}$ used for one person/day. Taking as average 
weight per person $70 \mathrm{~kg}$, the extrapolation gave $5 \mathrm{mg} / \mathrm{kg}$ BW which was multiplied by 10 to give $50 \mathrm{mg} / \mathrm{kg} \mathrm{BW}$ considered as pharmacological dose. In order to obtain a dose dependent effect, an intermediate dose of $150 \mathrm{mg} / \mathrm{kg}$ and a high dose of $300 \mathrm{mg} / \mathrm{kg}$ were obtained by multiplying the low dose by a factor of 3 .

\section{UPLC-HRMS analysis of EEP}

The fingerprints were performed using an UPLC Acquity system (Waters, Milford, MA, USA) to ensure a high resolving power and a baseline separation of most of the compounds in a reasonable separation time. All separations were performed on an Acquity UPLC BEH C18 column $(100 \mathrm{~mm} \times 2.1 \mathrm{~mm}$ I.D., $1.7 \mu \mathrm{m})$ at $25{ }^{\circ} \mathrm{C}$ with a flow rate of $0.400 \mathrm{~mL} / \mathrm{min}$. A guard column $(5 \mathrm{~mm} \times 2.1 \mathrm{~mm}, 1.7 \mu \mathrm{m})$ with the same stationary phase was placed before the column. The mobile phase consisted of water $+0.1 \%$ FA (solvent A) and $\mathrm{ACN}+0.1 \%$ FA (solvent B) and was used in multistep gradient mode. The gradient was operated as follow: isocratic 5\% B for $0.5 \mathrm{~min}, 5$ to $100 \% \mathrm{~B}$ for $17.5 \mathrm{~min}$, and a final isocratic step for $5 \mathrm{~min}$ at $100 \% \mathrm{~B}$. The sample manager was thermostated at $10{ }^{\circ} \mathrm{C}$, and the injection loop was set at $0.5 \mu \mathrm{L}$. The HRMS and HRMS/MS data were acquired with a mass range of $100-1500 \mathrm{~m} / \mathrm{z}$ using a XEVOG2QTOF instrument (Waters). ESI conditions operated in negative mode were as follow: source temperature $120{ }^{\circ} \mathrm{C}$, desolvation temperature $500{ }^{\circ} \mathrm{C}$; capillary voltage $1.5 \mathrm{KV}$, cone voltage $10 \mathrm{~V}$. Nitrogen was used as a cone $(10 \mathrm{~L} / \mathrm{h})$ and desolvatation gases $(1000 \mathrm{~L} / \mathrm{h})$. Lockspray flow rate was set at $20 \mu \mathrm{L} / \mathrm{min}$ and lockspray capillary at $2.5 \mathrm{KV}$. For the HRMS/MS acquisitions, a method including the detection (full scan) and fragmentation of the most intense peaks per scan was used. Collision energy was varying from 10 to $35 \mathrm{~V}$.

\section{Experimental organisms \\ Cell lines and cell culture}

The HEK293T - Human Embryonic Kidney 293 T cells line that contain the SV40 large T-antigen were purchased from ATCC (The Global Bioresource Center, Australia). Luciferase reporter construct was kindly provided by Dr Simon Chu (Hudson Institute of Medical Research, Australia). Cells were transfected using Lipofectamine Reagent obtained from Invitrogen (Sydney, Australia). The MCF7 - human ER-positive breast adenocarcinoma cells was obtained from the Rio de Janeiro Cell Bank (Federal University of Rio de Janeiro, Brazil).

HEK293T cells were cultured routinely in phenol red DMEM-F12 medium containing 10\% fetal calf serum (FCS), while MCF-7 cells were cultured in RPMI-1640 medium supplemented with $10 \%$ fetal bovine serum (FBS). All cell cultures were also supplemented with 100 $\mathrm{U} / \mathrm{mL}$ penicillin, $100 \mu \mathrm{g} / \mathrm{mL}$ streptomycin and $10 \mathrm{mM}$
HEPES. The cell cultures were maintained at $37^{\circ} \mathrm{C}$ in a $5 \% \mathrm{CO}_{2}$ humidified atmosphere and $\mathrm{pH}$ 7.4. Every two days, cells were passaged by removing $90 \%$ of the supernatant and replacing it with fresh medium. In all in vitro experiments, viable cells were checked at the beginning of the experiment by Trypan Blue dye exclusion test.

\section{Animals}

Healthy juvenile female Wistar rats aged 3 months $(\sim 150 \mathrm{~g})$ were obtained from the breeding facility of the Laboratory of Animal Physiology, University of Yaounde I (Cameroon). Animals were housed in clean plastic cages at room temperature (around $25^{\circ} \mathrm{C}$ ) under natural illumination (approx. $12 \mathrm{~h}$ light/dark). They had free access to a standard soy-free rat chow and water ad libitum. The composition of animal diet was: corn (36.7\%), bone flour (14.5\%), wheat (36.6\%), fish flour (4.8\%), crushed palm kernel $(7.3 \%)$, sodium chloride $(0.3 \%)$ and vitamin complex (Olivitazol $\left.{ }^{\circ}-0.01 \%\right)$.

\section{Ethical consideration}

Housing of animals and all experiments were approved by the Cameroon Institutional National Ethic Committee, which adopted all procedures recommended by the European Union on the protection of animals used for scientific purposes.

\section{Study design \\ Cell viability assay}

The Cytotoxicity of EEP was evaluated by Alamar Blue (resazurin) assay, in MCF-7 and HEK293T cells. This assay evaluates the mitochondrial production as a measurement of cell viability. For this, a density of $1 \times 10^{4}$ cells/well was seeded in a 96-well plate in $100 \mu \mathrm{L}$ of culture medium. After $24 \mathrm{~h}$ to permit their adhesion, cells were exposed for $24 \mathrm{~h}$ to the propolis extract at concentrations ranging from $10^{-5}$ to $10^{-1} \mu \mathrm{g} / \mathrm{mL}$ and $10^{-8}$ to $10^{-5} \mu \mathrm{g} / \mathrm{mL}$ for HEK293T and MCF-7 cells, respectively. Each experiment was performed in triplicate and repeated three times.

\section{Experiment 1: E-screen assay}

The MCF-7 cells proliferation assay was performed as described by Resende et al. [28]. Briefly, cells were trypsinized and seeded in 24-well plates at an initial concentration of $2 \times 10^{4}$ cells per well in RPMI supplemented with $10 \%$ FBS. After $24 \mathrm{~h}$ of incubation $\left(37^{\circ} \mathrm{C}, 5 \%\right.$ $\mathrm{CO}_{2}$ ) to permit their adhesion, cells were washed with phosphate-buffered saline (PBS) and the Serum Replacement $2(0.5 \times)$ supplemented phenol red-free RPMI was substituted for the seeding medium. EEP was added to the experimental medium at concentrations from $1 \times 10^{-8}$ to $1 \times 10^{-5} \mu \mathrm{g} / \mathrm{mL}$. For antiestrogenicity tests, before incubation, $1 \times 10^{-8} \mathrm{M}$ of $17 \beta$-estradiol was added to the wells. 
Cells treated with DMSO (0.01\%) and 10\% FBS in RPMI were solvent and medium controls, respectively. The steroid-free experimental medium serves as negative control while cells treated with $1 \times 10^{-8} \mathrm{M}$ of $17 \beta$-estradiol was positive control. The assay was stopped after $144 \mathrm{~h}$ by removing the medium from wells, fixing the cells with cold $10 \%$ trichloracetic acid and incubated at $4{ }^{\circ} \mathrm{C}$ for $1 \mathrm{~h}$. Thereafter, cells were washed four times with tap water and dried. Furthermore, cells were stained during $30 \mathrm{~min}$ with $0.057 \%(\mathrm{w} / \mathrm{v})$ sulforhodamine-B (SRB) dissolved in $1 \%$ acetic acid, rinsed four times with $1 \%$ acetic acid and air dried. Bound dye was solubilized with $10 \mathrm{mM}$ Tris base ( $\mathrm{pH} 10.5)$ in a shaker. Finally, aliquots were read in a Biotek EL800 Multiscan apparatus (Winoosky, USA) at $510 \mathrm{~nm}$. The estrogenic activity results were expressed as mean \pm standard error of mean (SEM) of the proliferative effect (PE), which was calculated according to Schiliro'et al. [29]: $P E=\max$ cell number of sample/cell number of $D M S O$ control. The estrogenic activity of a sample was determined as the relative proliferative effect (RPE\%). The RPE compares the maximum proliferation induced by a sample with that induced by $17 \beta$-estradiol: $R P E \%=[P E$ for sample/PE for $17 \beta$-estradiol] $\times 100$ [28].

\section{Experiment 2: transfections and luciferase assays}

The ability of EEP to activate $\alpha$ and $\beta$ estrogen receptors, in cell-based assays was tested. The Human Embryonic Kidney $293 \mathrm{~T}$ cells (HEK293T) were transiently transfected as previously described by Zingue et al. [30]. They were then treated with different concentrations (from $10^{-5}$ to $10^{-1} \mu \mathrm{g} / \mathrm{mL}$ ) of EEP for $24 \mathrm{~h}$. Cells treated with E2 alone served as positive control. Reporter gene assays in HEK293T-ER $\alpha$ cells and HEK293T-ER $\beta$ cells were performed using a commercial kit (Promega, Australia) according to the manufacturer's instructions. Luciferase activity was measured and normalised against $\beta$ galactosidase activity determined by using the 2nitrophenyl $\beta$-D-galactopyranoside (ONPG) method (Sigma-Aldrich, Sydney, Australia). Each experiment was performed at least in duplicate and repeated three times.

\section{Experiment 3: the 3-day uterotrophic assay}

Estradiol valerate, genistein and EEP were dissolved in distilled water $\left(\mathrm{dH}_{2} \mathrm{O}\right)$ used as vehicle in this experiment. Thirty female Wistar rats received a single intramuscular dose of long acting penicillin and diclofenac (10 $\mathrm{mg} / \mathrm{kg}$ and $3 \mathrm{mg} / \mathrm{kg}$ respectively) the day before ovariectomy. Thereafter they were bilaterally ovariectomized (OVX) using the dorsal approach under Diazepam and ketamin anesthesia (respectively $10 \mathrm{mg} / \mathrm{kg}$ and $50 \mathrm{mg} / \mathrm{kg} \mathrm{BW}$; i.p.). Fourteen days after ovariectomy (time necessary for endogenous hormonal decline), animals were randomly distributed into 6 groups of five animals each $(n=5)$ and treated once daily for 3 consecutive days by gavage with $10 \mathrm{~mL} / \mathrm{kg}$ of distilled water (OVX), $1 \mathrm{mg} /$ $\mathrm{kg}$ of estradiol valerate (E2V) and $10 \mathrm{mg} / \mathrm{kg}$ of genistein (GEN). The remaining three groups received EEP at doses of 50, 150 and $300 \mathrm{mg} / \mathrm{kg} \mathrm{BW}$. Twenty four hours after the last administration, animals were sacrificed by decapitation. Uteri were collected, trimmed of fat and wet weighed. Uterus, vagina, and mammary gland were fixed in $10 \%$ formalin for histological analyses. Estrogenic effects were evaluated based on uterine wet weight, the uterine and vagina epithelial heights, total uterine protein levels and mammary gland differentiation.

\section{Experiment 4: measurement of hot flushes}

The measurement of hot flushes have been made as previously described by Zingue et al. [30]. Data loggers were used to monitor the core temperature changes in the animals at 2 min intervals for $72 \mathrm{~h}$ and were preset to start measuring core temperatures $12 \mathrm{~h}$ before the beginning of the treatment until the end of treatment. A total of 35 acclimatized female rats were used in this experiment. A 4-cm long skin and abdominal musculature incisions were made in the cote region of abdomen under valium and ketamin anesthesia (respectively 10 and $50 \mathrm{mg} / \mathrm{kg}$ BW; i.p.). A data logger protected in sterilized neutral wax was placed in the abdominal cavity. Animals of group $1(n=6)$ were considered as control shamoperated (Sham) in which, the ovaries were exposed and gently manipulated but not excised and the other 30 animal were ovariectomized (OVX) as described above. The abdomen was closed with absorbable simple interrupted sutures in the muscle layer and skin. Animals of group 1 received distilled water as vehicle, while the 30 ovariectomized rats were randomly distributed into 6 groups of 5 animals each $(n=5)$ and treated for 3 days as described above. Twenty four hours after the last administration animals were sacrificed by decapitation, and the data loggers recovered. Data (central body temperature) was retrieved from loggers unto Excel spreadsheets and analyzed using the ACR Trend Reader for Smart Button Software. Substances were evaluated for their ability to affect core temperature; an average core temperature was calculated after every $6 \mathrm{~h}$ time point. The mean core temperature change ( $\Delta$ core temperature) was determined as previously described by Maswood et al. [31]. Hot flushes were considered for any internal temperatures $\geq 38^{\circ} \mathrm{C}$. The total number of hot flushes, the average of these hot flush durations and the frequency of hot flushes were determined as described by Zingue et al. [30].

\section{Histomorphological analysis}

The formalin-fixed tissues were embedded in paraffin, and sections of $5-\mu \mathrm{m}$ thickness were cut. Following hematoxylin-eosin staining, mammary gland differentiation, 
uterine and vaginal epithelial height were assessed on microphotography using the complete Zeiss equipment consisting of a microscope Axioskop 40 connected to a computer where the image was transferred, and analyzed with the MRGrab 1.0 and Axio Vision 3.1 softwares, all provided by Zeiss (Hallbermoos, Germany).

\section{Biochemical analysis}

Uterine total protein levels were determined in uteri using colorimetric methods described by Gonal et al. [32].

\section{Statistical analysis}

The data from each experimental group $(n=5)$ were expressed as mean \pm SEM. All graphs were plotted with Sigma Prism 5.0. One-way analysis of variance (ANOVA) followed by Dunnett's test for multiple comparisons and the Student's $t$ - test were used for statistical comparison between different control and treated groups for in vivo and in vitro experiments respectively. The significance of the difference was fixed at $p<0.05$.

\section{Results}

\section{Phytochemical analysis}

UPLC-HRMS analysis (Fig. 1 and Table 2) was carried out to identify compound from ethanolic extract of Cameroonian propolis. Briefly, all well resolved peaks in BPI were selected and possible elemental compositions (EC) were calculated. For reducing the possible EC candidates, mass tolerance was set below 3 ppm, only C, $\mathrm{H}, \mathrm{O}$ and $\mathrm{N}$ were selected for calculations and only consistent RDBeq values were considered. Additionally HRMS/MS data as well as bibliographic information were employed to identify the compounds. Furthermore dimeric ions $[2 \mathrm{M}-\mathrm{H}]^{-}$observed in case of triterpenoic compounds supported the confirmation of EC for the $[\mathrm{M}-\mathrm{H}]^{-}$ion. The detected compounds of PROMAX-C are summarised in Table 2 including their retention time, EC, $m / z$ (monoisotopic mass), RDBeq and their major HRMS/MS fragments. Identified metabolites are mainly caffeic acid derivatives and triterpenoids. Indeed, diverse caffeic acid derivatives already described in propolis extracts from Brazil and subSaharan African countries [33, 34] have been detected as caffeic acid 4-O-arabinoside $(\mathrm{m} / z=311.0768)$, caffeic acid 4-O-xyloside $(\mathrm{m} / \mathrm{z} 311.0768)$, caffeoylquinic acid $(\mathrm{m} /$ $z=353.0878)$, caffeic acid 4-O-glucoside $(\mathrm{m} / z=341.0868)$ and 3,4-dimethyl caffeic acid $(m / z=207.0656)$. Herein it was not possible to distinguish caffeic acid 4-O-arabinoside from caffeic acid 4-O-glucoside that is why they were noted as caffeic acid pentoside. In addition, two others common phenolic compounds in propolis were characterised: coumaric acid $(\mathrm{m} / z=163.0386)$ and phloretic acid $(m / z=165.0543)$ [14].

In addition several triterpenoids were well detected in Cameroonian propolis and putative identification was attempted comparing their ECs and fragmentation

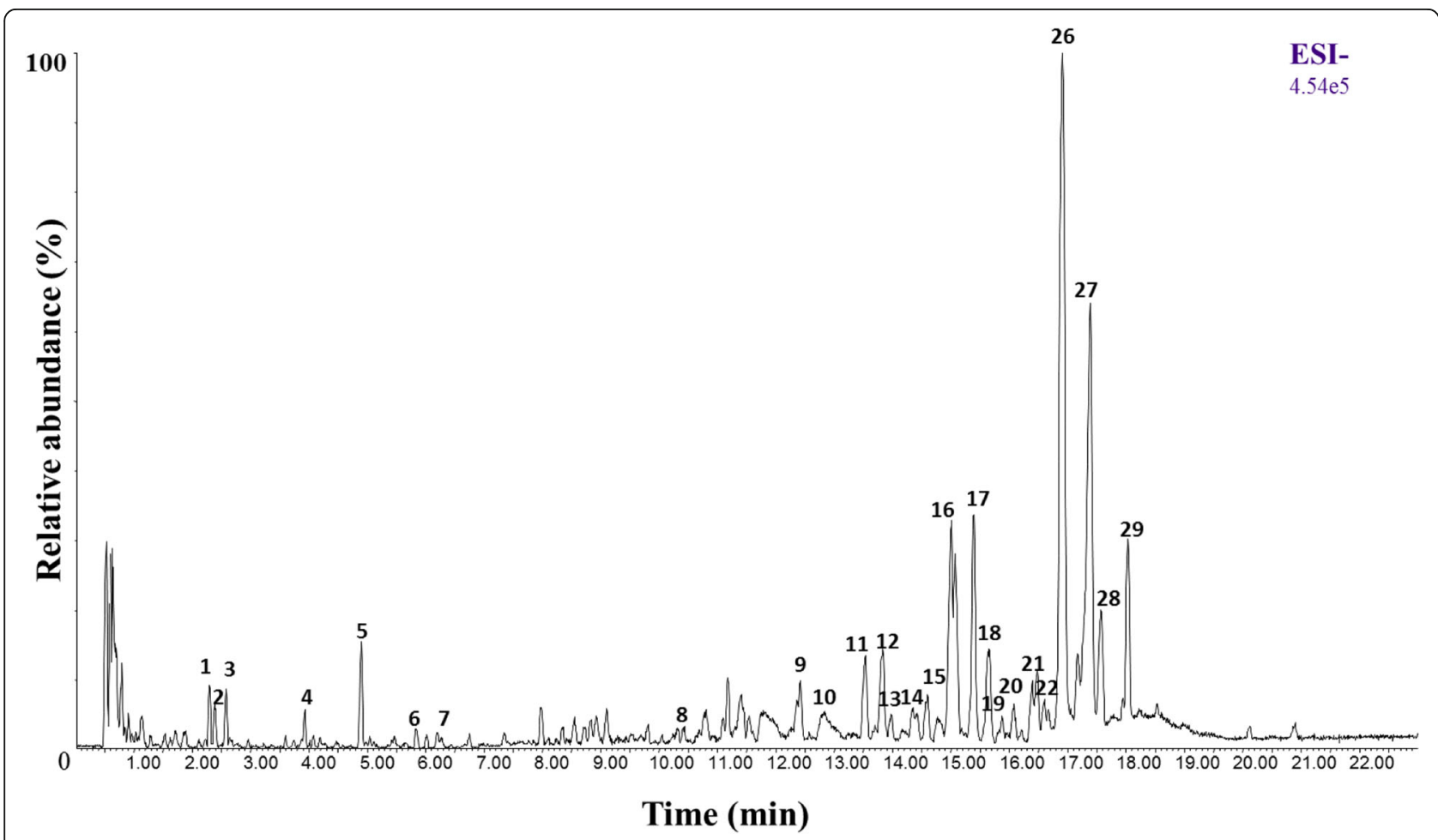

Fig. 1 UHPLC-ESI-HRMS base peak chromatogram of EEP in the negative ionisation mode 
Table 2 Summary of compounds separated and identified in Cameroonian propolis by UHPLC-ESI-HRMS analysis in the negative ion mode. Rt, $[\mathrm{M}-\mathrm{H}]^{-},[2 \mathrm{M}-\mathrm{H}]^{-}$, EC and RDBeq information are given together with main fragments at MS/MS level

\begin{tabular}{|c|c|c|c|c|c|c|c|c|c|}
\hline $\begin{array}{l}\text { Pick } \\
N^{\circ}\end{array}$ & $\operatorname{Tr}(\min )$ & $\begin{array}{l}{[\mathrm{M}-\mathrm{H}]^{-}} \\
(\mathrm{m} / \mathrm{z})\end{array}$ & $\begin{array}{l}{[2 \mathrm{M}-\mathrm{H}]^{-}} \\
(\mathrm{m} / \mathrm{z})\end{array}$ & EC & $\begin{array}{l}\text { Mass errors } \\
\text { (ppm) }\end{array}$ & RDBeq & $\begin{array}{l}\text { Fragment ions } \\
(\mathrm{m} / \mathrm{z})\end{array}$ & Tentative identification & References \\
\hline 1 & 2.30 & 311.0768 & & $\mathrm{C}_{14} \mathrm{H}_{15} \mathrm{O}_{8}$ & 0.3 & 7.5 & $\begin{array}{l}137.0236 \\
93.0335\end{array}$ & caffeic acid 4-O-pentoside & [33] \\
\hline 2 & 2.38 & 311.0768 & & $\mathrm{C}_{14} \mathrm{H}_{15} \mathrm{O}_{8}$ & 0.6 & 7.5 & $\begin{array}{l}137.0236 \\
93.0346\end{array}$ & caffeic acid 4-O-pentosside & [33] \\
\hline 3 & 2.60 & 341.0868 & & $\mathrm{C}_{15} \mathrm{H}_{17} \mathrm{O}_{9}$ & 1.5 & 7.5 & 167.0317 & Caffeic acid 4-O-glucoside & [33] \\
\hline 4 & 2.80 & 353.0878 & & $\mathrm{C}_{16} \mathrm{H}_{17} \mathrm{O}_{9}$ & 1.4 & 8.5 & $\begin{array}{l}191.0558 \\
173.0451\end{array}$ & caffeoylquinic acid & [34] \\
\hline 5 & 3.71 & 163.0386 & & $\mathrm{C}_{9} \mathrm{H}_{7} \mathrm{O}_{3}$ & -5.5 & 6.5 & & Coumaric acid & [14] \\
\hline 6 & 6.21 & 207.0656 & & $\mathrm{C}_{11} \mathrm{H}_{11} \mathrm{O}_{4}$ & -0.5 & 6.5 & & 3.4-Dimethyl caffeic acid (DMCA) & [33] \\
\hline 7 & 6.26 & 165.0543 & & $\mathrm{C}_{9} \mathrm{H}_{9} \mathrm{O}_{3}$ & -5.5 & 5.5 & & Phloretic acid & [34] \\
\hline 8 & 10.332 & 477.3204 & & $\mathrm{C}_{28} \mathrm{H}_{45} \mathrm{O}_{6}$ & -2.5 & 6.5 & $\begin{array}{l}431.3155 \\
415.2839\end{array}$ & Terpenoid derivative & \\
\hline 9 & 12.36 & 503.3375 & & $\mathrm{C}_{30} \mathrm{H}_{47} \mathrm{O}_{6}$ & 0.4 & 7.5 & $\begin{array}{l}487.3423 \\
441.3373\end{array}$ & Triterpenoid & \\
\hline 10 & 12.42 & 487.3424 & & $\mathrm{C}_{30} \mathrm{H}_{47} \mathrm{O}_{5}$ & 0.2 & 7.5 & & Triterpenoid & \\
\hline 11 & 13.503 & 473.3275 & & $\mathrm{C}_{29} \mathrm{H}_{45} \mathrm{O}_{5}$ & 1.7 & 7.5 & $\begin{array}{l}411.3252 \\
325.1831\end{array}$ & Triterpenoid & \\
\hline 12 & 13.7 & 469.3315 & & $\mathrm{C}_{30} \mathrm{H}_{45} \mathrm{O}_{4}$ & -0.6 & 8.5 & $\begin{array}{l}415.3215 \\
325.1845\end{array}$ & Triterpenoid & \\
\hline 13 & 13.82 & 487.3419 & & $\mathrm{C}_{30} \mathrm{H}_{47} \mathrm{O}_{5}$ & -0.8 & 7.5 & 425.3147 & Triterpenoid & \\
\hline 14 & 14.399 & 485.3278 & & $\mathrm{C}_{30} \mathrm{H}_{45} \mathrm{O}_{5}$ & 2.3 & 8.5 & $\begin{array}{l}471.3471 \\
441.3362\end{array}$ & Triterpenoid & \\
\hline 15 & 14.57 & 487.3427 & & $\mathrm{C}_{30} \mathrm{H}_{47} \mathrm{O}_{5}$ & 0.8 & 7.5 & 459.347 & Triterpenoid & \\
\hline 16 & 15.01 & 485.3278 & & $\mathrm{C}_{30} \mathrm{H}_{45} \mathrm{O}_{5}$ & 0 & 8.5 & $\begin{array}{l}433.3362 \\
325.1843\end{array}$ & Triterpenoid & \\
\hline 17 & 15.07 & 471.3468 & & $\mathrm{C}_{30} \mathrm{H}_{47} \mathrm{O}_{4}$ & 0.5 & 7.5 & $\begin{array}{l}453.3362 \\
427.357\end{array}$ & $\begin{array}{l}\text { Maslinic or corosolic or } \\
\text { cycloanostoic acid derivatives }\end{array}$ & {$[13,38]$} \\
\hline 18 & 15.374 & 469.3315 & & $\mathrm{C}_{30} \mathrm{H}_{45} \mathrm{O}_{4}$ & -0.6 & 8.5 & 425.3418 & Triterpenoid & \\
\hline 19 & 15.857 & 299.2596 & & $\mathrm{C}_{18} \mathrm{H}_{35} \mathrm{O}_{3}$ & 0.3 & 1.5 & & 3-hydroxystearic acid & \\
\hline 20 & 16.2 & 431.3159 & & $\mathrm{C}_{27} \mathrm{H}_{43} \mathrm{O}_{4}$ & -0.5 & 6.5 & 369.3164 & Terpenoid derivative & \\
\hline 21 & 16.40 & 455.3513 & 911.7104 & $\mathrm{C}_{30} \mathrm{H}_{47} \mathrm{O}_{3} \mathrm{C}_{60} \mathrm{H}_{95} \mathrm{O}_{6}$ & $-2.4-2.7$ & $\begin{array}{l}7.5 \\
13.5\end{array}$ & & $\begin{array}{l}\text { Mangiferolic or isomangiferolic } \\
\text { acids }\end{array}$ & \\
\hline 22 & 16.42 & 501.3576 & & $\mathrm{C}_{31} \mathrm{H}_{49} \mathrm{O}_{5}$ & -0.8 & 7.5 & & Triterpenoid & \\
\hline 23 & 16.46 & 469.3313 & 939.6696 & $\mathrm{C}_{30} \mathrm{H}_{45} \mathrm{O}_{4} \mathrm{C}_{60} \mathrm{H}_{91} \mathrm{O}_{8}$ & $\begin{array}{l}-1.1 \\
-2.7\end{array}$ & $\begin{array}{l}8.5 \\
13.5\end{array}$ & & Ambolic acid & \\
\hline 24 & 16.63 & 453.3368 & 907.6818 & $\mathrm{C}_{30} \mathrm{H}_{45} \mathrm{O}_{3} \mathrm{C}_{60} \mathrm{H}_{91} \mathrm{O}_{6}$ & $\begin{array}{l}-0.2 \\
-0.2\end{array}$ & $\begin{array}{l}8.5 \\
15.5\end{array}$ & & Mangiferonic acid & \\
\hline 25 & 16.91 & 471.347 & 943.7007 & $\mathrm{C}_{30} \mathrm{H}_{47} \mathrm{O}_{4} \mathrm{C}_{60} \mathrm{H}_{95} \mathrm{O}_{8}$ & $\begin{array}{l}-0.8 \\
-2.1\end{array}$ & $\begin{array}{l}7.5 \\
13.5\end{array}$ & 409.3465 & $\begin{array}{l}\text { Maslinic or corosolic or } \\
\text { cycloanostoic acid derivatives }\end{array}$ & {$[13,38]$} \\
\hline 26 & 17.17 & 471.3467 & & $\mathrm{C}_{30} \mathrm{H}_{47} \mathrm{O}_{4}$ & -0.4 & 7.5 & $\begin{array}{l}455.3512 \\
393.3148\end{array}$ & $\begin{array}{l}\text { Maslinic or corosolic or } \\
\text { cycloanostoic acid derivatives }\end{array}$ & {$[13,38]$} \\
\hline 27 & 17.38 & 471.3467 & & $\mathrm{C}_{30} \mathrm{H}_{47} \mathrm{O}_{4}$ & -0.8 & 7.5 & $\begin{array}{l}409.347 \\
393.3148\end{array}$ & $\begin{array}{l}\text { Maslinic or corosolic or } \\
\text { cycloanostoic acid derivatives }\end{array}$ & {$[13,38]$} \\
\hline 28 & 17.96 & 455.3525 & & $\mathrm{C}_{30} \mathrm{H}_{47} \mathrm{O}_{3}$ & -2 & 7.5 & & $\begin{array}{l}\text { Mangiferolic or isomangiferolic } \\
\text { acids }\end{array}$ & \\
\hline 29 & 18.02 & 457.3676 & 915.7413 & $\mathrm{C}_{30} \mathrm{H}_{49} \mathrm{O}_{3} \mathrm{C}_{60} \mathrm{H}_{99} \mathrm{O}_{6}$ & $\begin{array}{l}-1.3 \\
-2.1\end{array}$ & $\begin{array}{l}6.5 \\
11.5\end{array}$ & 457.3644 & Ocotillone isomer & {$[38]$} \\
\hline
\end{tabular}


pathway with those reported in literature and databases (Table 2). The detected triterpenoids exhibit the $\mathrm{C}_{30}$ skeleton characteristic of this family, the number of hydrogen atoms was varying from 43 to 50, and the oxygen atom numbers ranged from three to six. Concerning the fragmentation patterns, their HRMS/MS spectra were dominated by typical neutral loss of 18, 28, 44 and 62 which could be assigned to $\mathrm{H}_{2} \mathrm{O}, \mathrm{CO}, \mathrm{CO}_{2}$ and $\mathrm{H}_{2} \mathrm{O}+\mathrm{CO}_{2}$, respectively. It is worthwhile to note that these typical losses have already been observed for triterpenoids fragmentation in negative mode using either ESI or Atmospheric Pressure Photo Ionisation (APPI) sources [35, 36].

Among them, several triterpenoids were detected at $\mathrm{m} /$ $\mathrm{z}=455.3513\left(\mathrm{C}_{30} \mathrm{H}_{47} \mathrm{O}_{3}\right)$ and $\mathrm{m} / \mathrm{z}=471.3468\left(\mathrm{C}_{30} \mathrm{H}_{47} \mathrm{O}_{4}\right)$ which corresponds to pentacyclic triterpenoids structure. Some pseudo molecular ions could be attributed to triterpenoids already found in Cameroonian propolis [37] such as mangiferolic or isomangiferolic acids $(\mathrm{m} / z=455.3513)$, magiferonic acid $(m / z=453.3368)$ and ambolic acid $(\mathrm{m} / \mathrm{z}$ 469.3315 ), while the ion at $\mathrm{m} / \mathrm{z}=471.3468$ could be originated from maslinic and corosolic acids already detected in Thai propolis [38] or cycloanostoic acid derivatives from Cretan propolis [13]. Sanpa et al. [38] also idenfied two isomers of ocotillone, tetracyclic triterpenoids, which might correspond to the ion found at $\mathrm{m} / z=457.3676$. Compound detected at $m / z=485.3278\left(\mathrm{C}_{30} \mathrm{H}_{45} \mathrm{O}_{5}\right)$ share same molecular formula than (24E)-3-oxo-27,28-dihydroxycycloart-24-en-26-oic acid found in propolis from Burma [39]. Studying main fragment ions, it can be observed formation of ion at $\mathrm{m} / \mathrm{z}=425.3418\left(\mathrm{C}_{30} \mathrm{H}_{49} \mathrm{O}\right)$ corresponding to derivatives of amyrin isomers or lupeol mainly present in Cameroonian propolis [37]. However data were not sufficient to confirm the structure of these compounds and differentiate them.

\section{In vitro estrogenicity assessment Cytotoxicity}

Ethanolic extract of propolis did not induced cytotoxic effects in both MCF-7 and HEK293T cells at tested concentrations (Figs. 2a and 3a).

\section{E-screen assay}

Effects of EEP on MCF-7 cells proliferation are depicted in Table 3 and Fig. 2 . It can be observed that 17- $\beta$ estradiol induced a significant $(p<0.001)$ increased of MCF-7 cells yield. EEP induced a significant $(p<0.05)$ increase of MCF-7 cells yield only at the concentration of $0.1 \mu \mathrm{M}$ as compared to DMSO control. Further, a significant and concentration-dependant antiestrogenic effect was noted with EEP.

\section{Transactivation assay}

EEP activated ER $\alpha$ and ER $\beta$ at all tested doses, but it did not exhibit agonistic activity (Fig. 3). Interestingly when
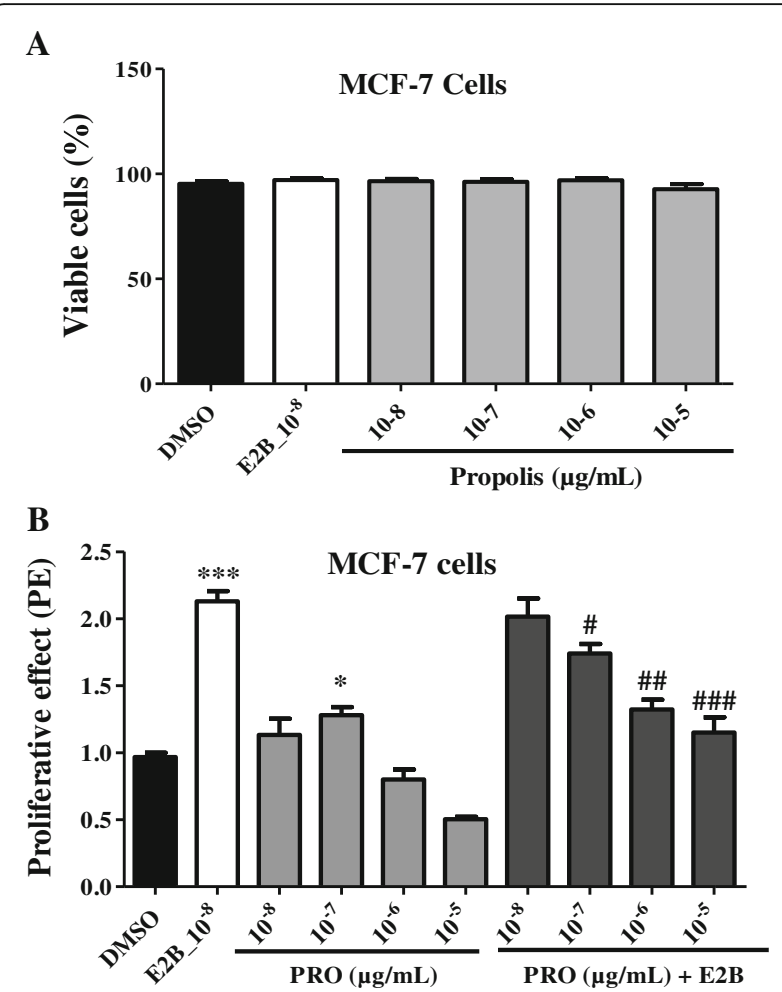

Fig. 2 Effects of EEP on MCF-7 cells proliferation. Its effect was investigated by measuring E-screen assay. The relative MCF-7 cells yields (PE) were measured in the presence of DMSO (0.01\%), 17 $\beta$-estradiol $(E 2 B, 10 \mathrm{nM})$ and EEP (PRO). PE = max cell number of sample/cell number of DMSO control; * $p<0.05,{ }^{* * *} p<0.001$ as compared to the DMSO control

cotreated with E2, the high concentrations (0.01 and $0.1 \mu \mathrm{g} / \mathrm{mL}$ ) of EEP significantly antagonized E2-activation of both receptor subtypes.

\section{In vivo estrogenicity assessment}

Effects on the uterine wet weight and total protein levels in uterine

As shown in Fig. 4a, a 3-day oral administration of EEP induced a significant increase in the uterine wet weight and total uterine protein levels at all tested doses in a bell shape dose response. The maximum increase for these two parameters was obtained at the dose of $150 \mathrm{mg} / \mathrm{kg}$ $\mathrm{BW}(p<0.01)$. However, this increase remained much lower than in E2V-treated group.

\section{Effects on the uterine epithelium}

As depicted in Fig. 4c, following a 3-day treatment with EEP, uterine epithelial height significantly increased by $58.5 \%(p<0.05)$ only at dose of $150 \mathrm{mg} / \mathrm{kg} \mathrm{BW}$. However these increases remained much lower than that induced by E2V at the dose of $1 \mathrm{mg} / \mathrm{kg} \mathrm{BW}$, which showed a 3.5fold $(p<0.01)$ increase of uterine epithelial height but seems to be higher than those induced by genistein 
A

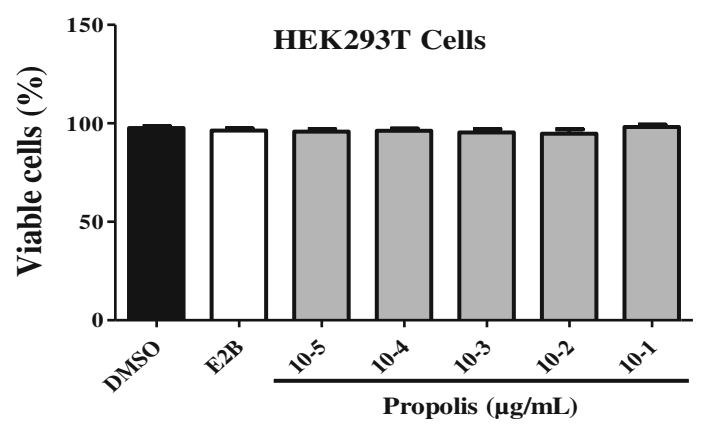

B

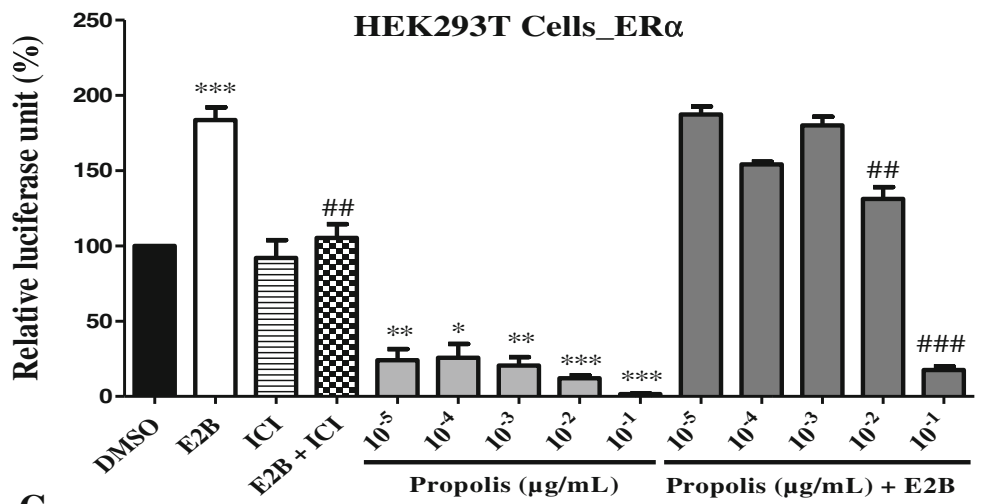

C

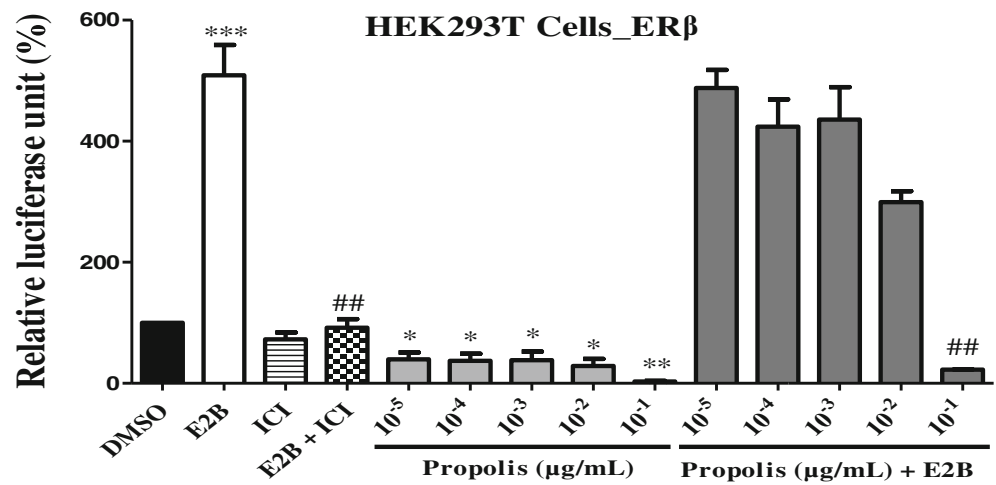

Fig. 3 Effects of EEP on the activation of estrogen $a$ and $\beta$ receptors in HEK293T cells. The effect of EEP on estrogen a and $\beta$ receptors activity in the transiently transfected HEK293T-ERa and HEK293T-ERß cells was investigated by measuring reporter gene-coupled luciferase activity. The relative luciferase units (RLU) were measured in the presence of DMSO (0.1\%), E2B (10 nM) and Cameroonian propolis; ${ }^{*} p<0.05,{ }^{* *} p<0.01,{ }^{* * *} p<0.001$ as compared with control

$(10 \mathrm{mg} / \mathrm{kg})$. These effects were materialized in histological sections by an atrophic uterus with cuboidal endometrial epithelium and loose connective tissue composed of round nuclei in an unorganized pattern in animals of OVX group. While in the E2V treated-group, all structures are hypertrophic and hyperplastic; the endometrium is multilayered with squamous metaplasia and atypic mitotic figure surrounded by anaplastic epithelial nuclei (Fig. 4d). Microphotographs of animals that received EEP at the dose of $150 \mathrm{mg} / \mathrm{kg}$ displayed an endometrium consisting of tall single-layered epithelial cells with abundant mitotic figures and necrosis (arrowhead), however, this effect is less than those observe in E2V-treated group.

\section{Effects on the vaginal epithelium}

Figure 5 represents vaginal epithelial heights. The microphotographs of vaginal epithelium of the OVX group showed an atrophic vaginal epithelium, consisting simply of the stratum germinativum (Ge) which is composed of a few layers of flattened cells (Fig. 5a). After genistein $(10 \mathrm{mg} / \mathrm{kg})$ treatment, vaginal epithelium became hypertrophic and hyperplasic (Gr), with cornification (Co) in the upper layers. While E2V (1 $\mathrm{mg} / \mathrm{kg})$ induced a 
Table 3 Effects of EEP in MCF-7 cells proliferation assay

\begin{tabular}{llll}
\hline Group & Concentration $(\mu \mathrm{g} / \mathrm{mL})$ & PE & RPE $(\%)$ \\
\hline DMSO & - & $1 \pm 0.03$ & 47.17 \\
E2B $\left(10^{-8} \mathrm{M}\right)$ & $10^{-8}$ & $2.12 \pm 0.13$ & 100 \\
Propolis & $10^{-8}$ & $1.21 \pm 0.15$ & 57.07 \\
& $10^{-7}$ & $1.32 \pm 0.18$ & 62.26 \\
& $10^{-6}$ & $0.72 \pm 0.08$ & 33.96 \\
& $10^{-5}$ & $0.48 \pm 0.16$ & 22.64 \\
& $10^{-8}$ & $1.95 \pm 0.03$ & 91.98 \\
Propolis & $10^{-7}$ & $1.72 \pm 0.19$ & 81.13 \\
E2B $\left(10^{-8} \mathrm{M}\right)$ & $10^{-6}$ & $1.31 \pm 0.06$ & 61.79 \\
& $10^{-5}$ & $1.21 \pm 0.15$ & 57.07
\end{tabular}

$D M S O$ negative control, E2B Estradiol benzoate, served as positive control, $P E$ Proliferative effect calculated as the effect on solvent control, RPE Relative proliferative effect, compares the maximum proliferation induced by a sample with that induced by $17 \beta$-estradiol

stronger hypertrophy and hyperplasia of vaginal epithelium. EEP also induced hypertrophic and hyperplasic effects at all tested doses with cornification at the dose of $150 \mathrm{mg} / \mathrm{kg}$. However compared to E2V there are less cell layers and a lower degree of cornification.

The graphical representation of the vaginal epithelial height (Fig. 5b) shows that E2V induced a 5-fold $(p<0.01)$ increase of vaginal epithelial height. EEP significantly $(p<0.01)$ and in the bell shaped dose response manner increased vaginal epithelial height at all tested doses. The maximum increment of 2.2-fold was obtained at the dose of $150 \mathrm{mg} / \mathrm{kg} \mathrm{BW}$ (from $4.06 \pm 0.21$ to $9.47 \pm 1.07 \mu \mathrm{m}$ ) as compared to the OVX group.

\section{Effects on mammary glands}

Figure 6 presents sections of mammary glands. Ovariectomy induced an atrophy of mammary gland which is materialized in OVX-histological section by a modest alveolar development, a small cluster of densely packed epithelial cells without luminal formation are present in the deep subcutaneous fat pad, the loss of the gland parenchyma (Tc) and the ductular and alveolar components, while adipocyte tissue (At) appears prominent. Mammary glands of genistein-treated group depict a few terminal structures with small lumina with secretory material; while mammary glands of E2V-treated group present well-formed acinar and luminal structures, an increase in proliferative activity compared to OVX group such as increase of the diameter and the lumen of alveoli, abundant eosinophil secretion (Se) in lumen of alveoli and further compression of stromal fat. Similar changes were noticed after a 3-days treatment with EEP at all tested doses but only the dose of $150 \mathrm{mg} / \mathrm{kg} \mathrm{BW}$ presented an eosinophil secretion in their lumens.

\section{Effects of EEP on hot flushes}

\section{Effect on core temperature}

In Fig. 7, the result displayed shows that the OVXuntreated group had an average core temperature higher than those of sham operated group and all treated groups (Fig. 7a and b). In this study, core temperature peaked between 10:00 PM and 04:00 AM in all experimental groups. Rats treated with standard drugs (E2V and genistein) had lower temperature peaks compared to the OVX animals (Fig. 7a). Similar changes were observed following treatment with EEP at the dose of $150 \mathrm{mg} / \mathrm{kg}$ (Fig. 7b).

Figure $7 \mathrm{c}, \mathrm{d}$ and Table 4 show the mean core temperature changes. The mean and maximum core temperature changes were significantly higher in OVX group than normal animals (Sham) $(p<0.05)$ (Fig. 7c, d and Table 4). E2V and genistein treatments significantly reduced the core temperature changes as compared to OVX group $(p<0.05)$. Importantly, EEP has significantly reduced the core temperature changes $(p<0.05)$ at the dose of $150 \mathrm{mg} / \mathrm{kg}$ ) (Table 4).

\section{Effects on total number and average duration of hot flushes}

If we consider any core temperatures $\geq 38{ }^{\circ} \mathrm{C}$ as hot flushes, ovariectomy significantly increased the total number of hot flushes in OVX animals as compared to normal animals (Sham) $(p<0.01)$. E2V-treatment significantly decreased the total number of hot flushes by $28.5 \%$ (from $29.4 \pm 2.2$ to $21.1 \pm 2.42$ hot flushes) as compared to OVX group. Moreover, 3-days of oral administration of EEP significantly reduced the total number of hot flushes by $21.8 \%$ at doses of $50 \mathrm{mg} / \mathrm{kg}$ and by $20.7 \%$ at the dose of $150 \mathrm{mg} / \mathrm{kg} \mathrm{BW}$ (Fig. 8a).

Fourteen days after ovariectomy, the average duration of hot flushes significantly increased in OVX animals as compared to normal animals (Sham) $(p<0.001)$. Treatment with estradiol (E2V) and genistein (GEN) significantly reduced this parameter $(p<0.01)$. The administration of EEP induced a significant $(p<0.001)$ decrease in the average duration of hot flushes only at doses of $150 \mathrm{mg} / \mathrm{kg} \mathrm{BW}$ (Fig. 8b).

\section{Effects on frequency of hot flushes}

All the studied groups presented a fluctuation in the number of hot flushes by a $6 \mathrm{~h}$ period between high and low values. Ovariectomy significantly increased the frequency of hot flushes at $6 \mathrm{~h}$ intervals as compared to normal group (Sham) $(p<0.01)$. More importantly, in the meantime, values in OVX untreated animals were much higher than for Sham operated and all treated groups. As shown in Fig. 9, EEP at the dose of $150 \mathrm{mg} /$ $\mathrm{kg} \mathrm{BW}$ significantly reduced $(p<0.01)$ the frequency of hot flushes. 


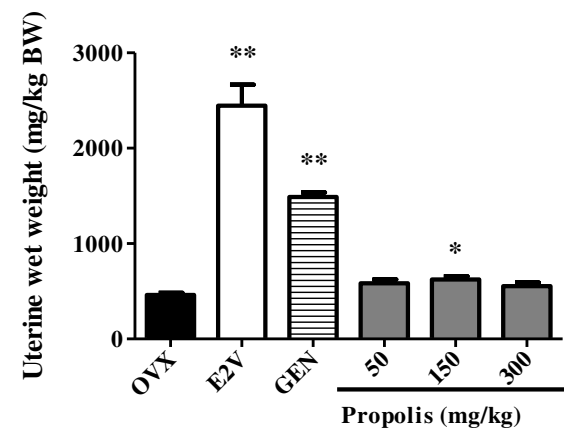

A

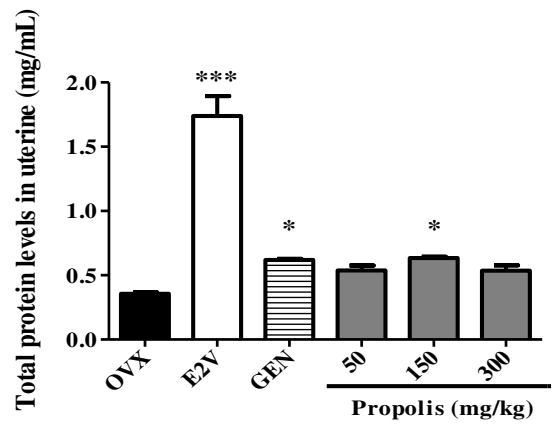

B

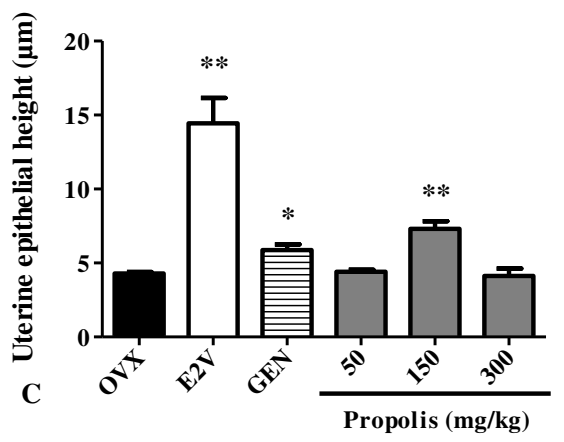

D

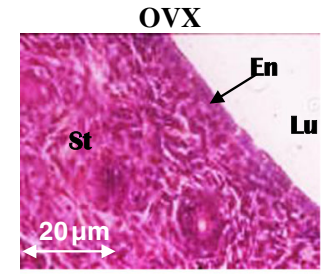

Propolis 50

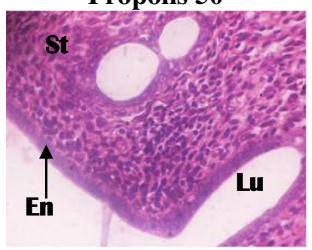

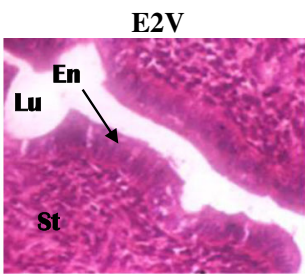

Propolis 150

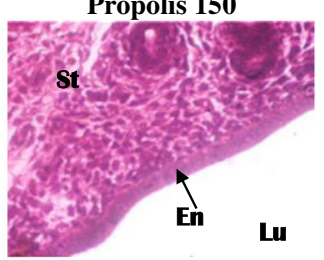

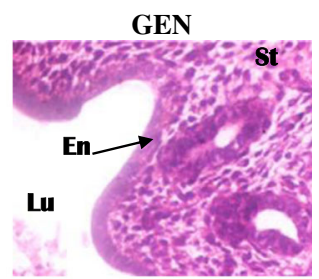

Propolis 300

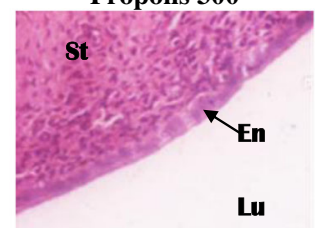

Fig. 4 Effects of a 3-day treatment with EEP on the uterine wet weight (a), total protein levels in uterine (b), uterine epithelial height (c) and microphotographs (d). OVX = OVX animals treated with the vehicle; E2V=OVX animals treated with estradiol valerate at $1 \mathrm{mg} / \mathrm{kg}$ BW; GEN = OVX animals treated with genistein at $10 \mathrm{mg} / \mathrm{kg} \mathrm{BW}$; Propolis = OVX animals treated with EEP at doses of 50,150 and $300 \mathrm{mg} / \mathrm{kg}$ BW. ${ }^{*} p<0.05,{ }^{* *} p<0.01$ as compared with control. Lu: uterine lumen; En: Endometrium; St: Stroma

\section{Discussion}

Ethanolic extract of Cameroonian propolis is widely used by Cameroonian population in folk medicine for the treatment of multiple health problems, including gynecological complaints and amenorrhea, which has never been assessed scientifically. Previous reports show that, components of propolis were qualitatively and quantitatively variable, depending on the regional plant ecology surrounding the bee hive. As depicted in Table 1, analyses of numerous Cameroonian propolis samples from Adamawa geographical zones display differences on chemical composition, which in turn influences its biological activity. It is well documented that phenolic compounds constitute the most numerous group of propolis components with respect to the quantity and type out of which flavonoids are the most abundant [40]. Many scientific reports on Cameroonian propolis corroborate this assertion and conclude that total polyphenols contents in Cameroonian propolis fall within the range of values reported for propolis from other countries [21, 24, 26, 27]. More precisely, Njintang et al. [23] reported that the polyphenols content in PROMAX-C samples varied from 186 to $1084 \mathrm{mg} / \mathrm{L}$. This high variability of polyphenols amount in different propolis samples has been attributed to the change of regional plants visited by honeybees. The phytochemical analysis 


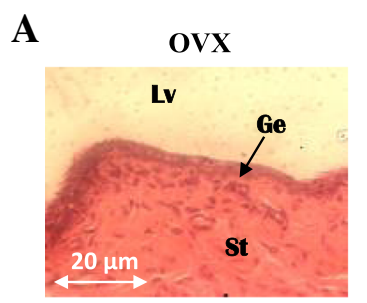

Propolis 50

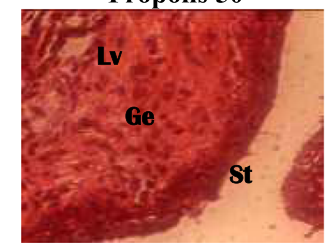

B
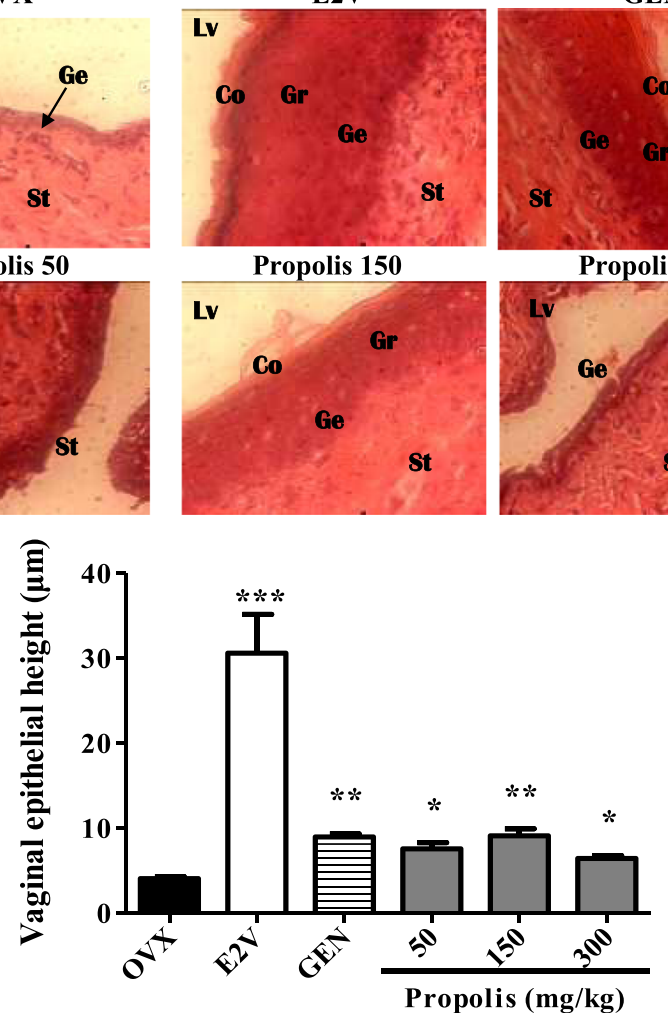

Fig. 5 Effects of a 3-day treatment with EEP on the vaginal epithelium: microphotographs (a) and epithelial height (b). OVX=OVX animals treated with the vehicle; $\mathrm{E} 2 \mathrm{~V}=\mathrm{OVX}$ animals treated with estradiol valerate at $1 \mathrm{mg} / \mathrm{kg} \mathrm{BW;} \mathrm{GEN} \mathrm{=OVX}$ animals treated with genistein at $10 \mathrm{mg} / \mathrm{kg} B W$; Propolis $=$ OVX animals treated with EEP at doses of 50, 150 and $300 \mathrm{mg} / \mathrm{kg} \mathrm{BW.}{ }^{*} p<0.05,{ }^{* *} p<0.01$ as compared with control. Lv $=$ vaginal lumen, $\mathrm{Co}=$ stratum corneum, $\mathrm{Gr}=$ stratum granulosum, $\mathrm{Ge}=$ stratum germinativum, St: Stroma

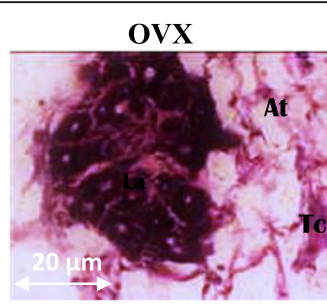

Propolis 50
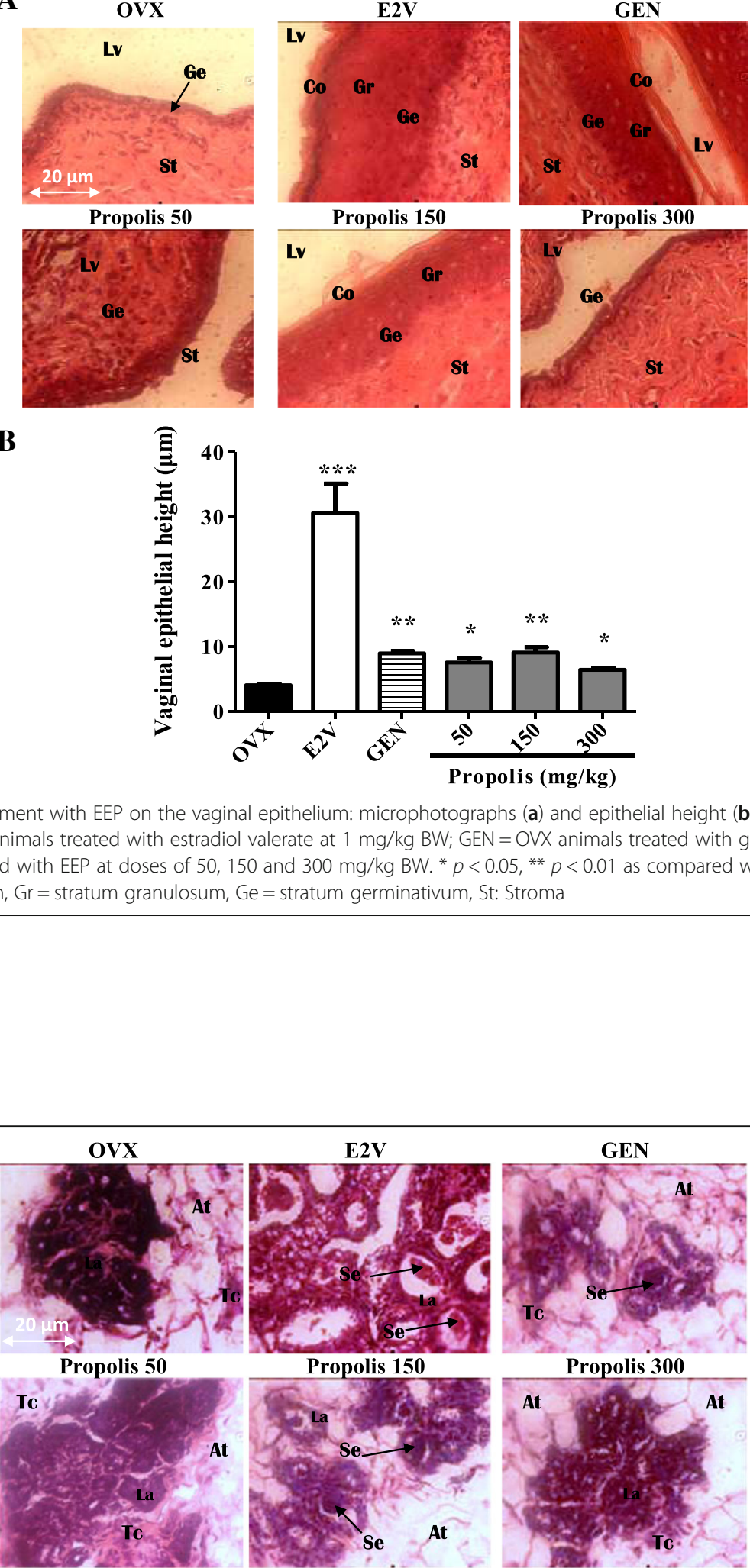

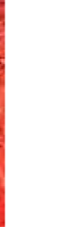




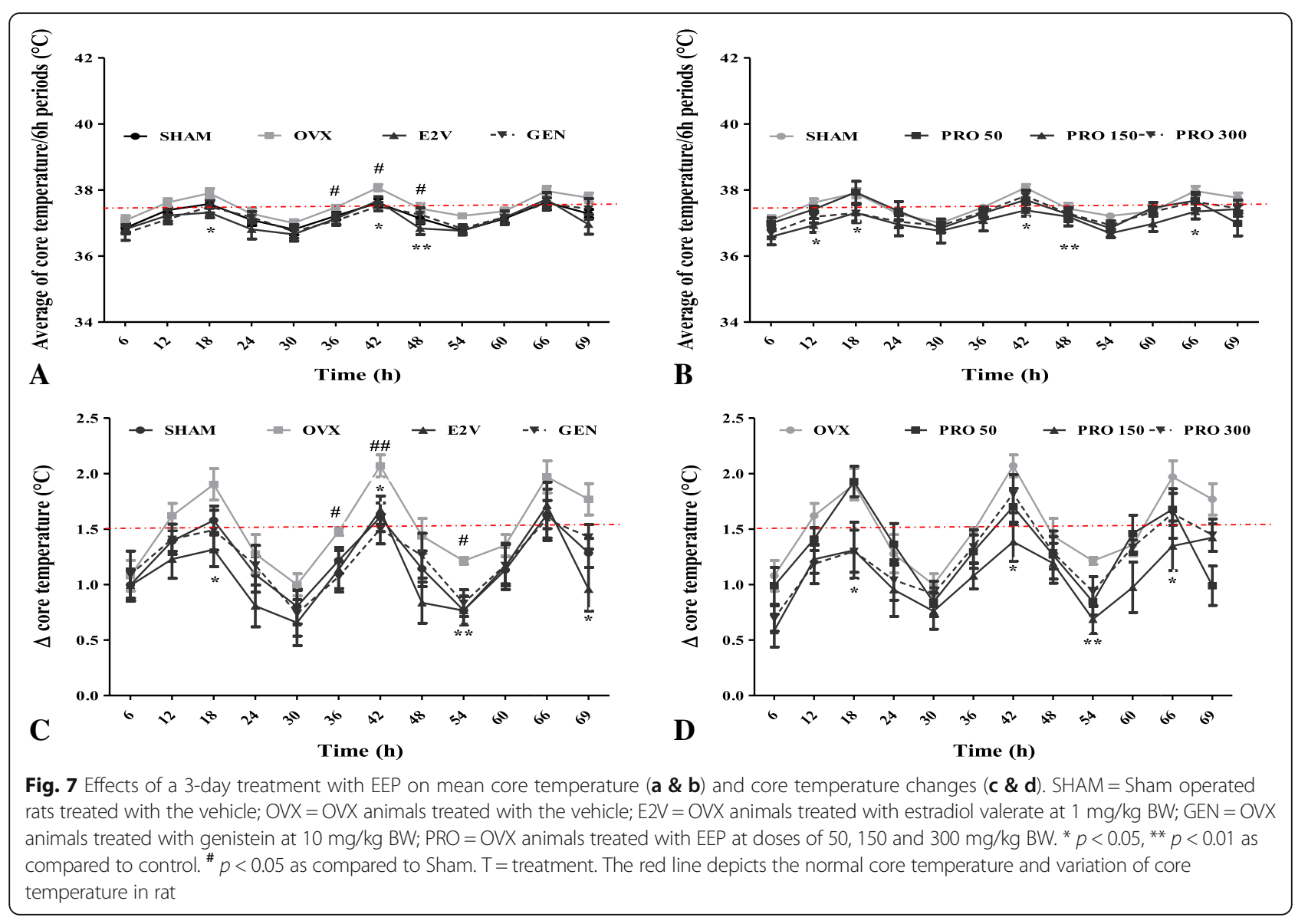

performed on Cameroonian propolis sample studied is in agreement with previous reports. We found a large range of polyphenols, specially, caffeic acid derivatives.

Song et al. [15] reported that ethanolic extract of Korean propolis displays estrogenic activity in estrogendependent MCF-7 cells, recombinant ER- $\alpha$, yeast estrogen receptor transcription system and immature female rats and authors concluded that these effects was initiated through estrogen receptors. In this study, EEP induced a weak estrogenic activity in vitro by increasing the MCF-7

Table 4 Effects of EPP on core temperature changes $(\Delta)$

\begin{tabular}{lll}
\hline Groups & $\begin{array}{l}\text { Mean } \Delta \text { Core } \\
\text { temperature }\left({ }^{\circ} \mathrm{C}\right)\end{array}$ & $\begin{array}{l}\text { Max } \Delta \text { Core } \\
\text { temperature }\left({ }^{\circ} \mathrm{C}\right)\end{array}$ \\
\hline Sham & $1.22 \pm 0.13$ & $1.63 \pm 0.23$ \\
OVX & $1.5 \pm 0.15 \#$ & $2.07 \pm 0.10 \#$ \\
E2V & $1.1 \pm 0.15^{* *}$ & $1.71 \pm 0.21^{*}$ \\
GEN & $1.23 \pm 0.12^{*}$ & $1.59 \pm 0.17^{*}$ \\
Propolis 50 & $1.35 \pm 0.13$ & $1.60 \pm 0.16$ \\
Propolis 150 & $1.09 \pm 0.10^{* *}$ & $1.40 \pm 0.32^{* *}$ \\
Propolis 300 & $1.27 \pm 0.12$ & $1.55 \pm 0.21^{*}$ \\
\hline
\end{tabular}

${ }^{*} p<0.05,{ }^{* *} p<0.01$ as compared to OVX control. ${ }^{\#} p<0.05,{ }^{\# \#} p<0.01$ as compared to Sham cells yield but, it did not induce transactivation of reporter gene activity at all tested doses in both HEK293T ER- $\alpha$ and ER- $\beta$ cell systems used in this work. However, it seems to possess antiestrogenic activity when increasing concentrations. These results can be explained by the presence in EEP of caffeic acid derivatives, since caffeic acid phenethyl ester (CAPE), an abundant phenolic ester in propolis is well known to exhibit estrogenic activity. Indeed, Jung et al. [16] demonstrated that CAPE is responsible for, among others, of the estrogenic/antiestrogenic effects of propolis. They showed that CAPE is a selective agonist to ER- $\beta$, which does not show any estrogenic effect on estrogen receptor-positive breast cancer cells and in immature rat uterine tissue. For these reasons authors claim that CAPE is a potential modulator of the estrogen receptor [16]. Due to the fact that chemical composition of propolis is highly variable mainly due to the variability of plant species growing around the hive [12], the different amount of caffeic acid derivatives in Cameroonian propolis that in Korean propolis can account for its antagonist effects observed in vitro at the tested doses. It has been reported that CAPE preferentially binds to ER $\beta$ and that $E R \beta$ isoform is involved in anti-proliferative mechanisms [41]. Chemical composition of propolis greatly varies 


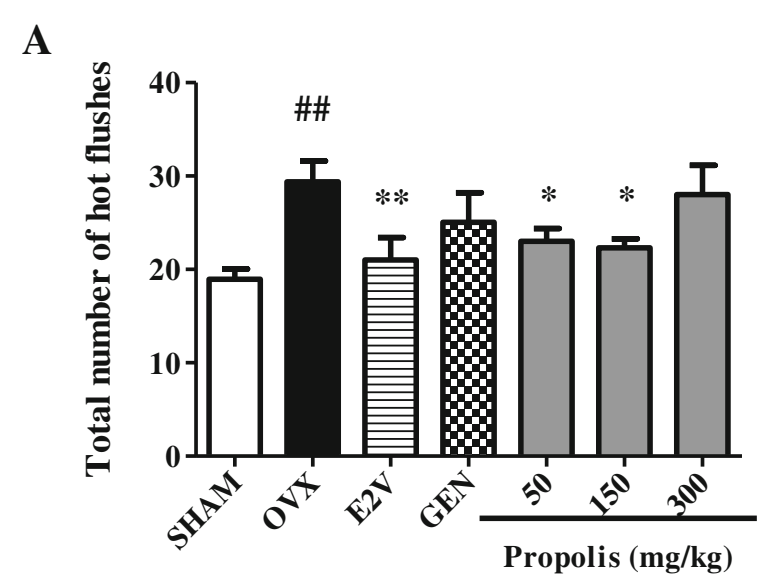

B

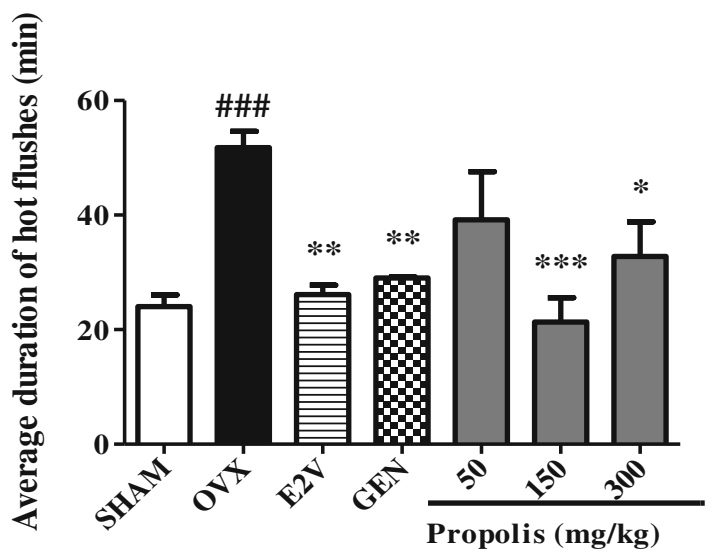

Fig. 8 Effects of a 3-day treatment with EEP on total number (a) and average duration (b) of hot flushes. SHAM = Sham operated rats treated with the vehicle; OVX $=$ OVX animals treated with the vehicle; $\mathrm{E} 2 \mathrm{~V}=\mathrm{OVX}$ animals treated with estradiol valerate at $1 \mathrm{mg} / \mathrm{kg} \mathrm{BW}$; $\mathrm{GEN}=$ OVX animals treated with genistein at $10 \mathrm{mg} / \mathrm{kg} \mathrm{BW}$; Propolis = OVX animals treated with EEP at doses of 50, 150 and $300 \mathrm{mg} / \mathrm{kg} \mathrm{BW}$. * $p<0.05$, ** $p<0.01$ as compared to control. " $p<0.05$, \#\# $p<0.01$, \#\#\# $p<0.001$ as compared to Sham

according to the plants that can be found in a specific region [18, 19]. The caffeic acid derivatives has been detected as potential estrogenic components in Cameroonian and Korean propolis, while Okamoto et al. [42] attributed the estrogenic effects of Brazilian propolis to the well-known phytoestrogens Kaempferol, quercetin, naringenin, Biochanin $\mathrm{A}$ and formononetin. These aforesaid suggest a regional difference in estrogenic components of propolis.

In this study, ovariectomy induced a decrease of uterine wet weight, uterine and vaginal epithelial height and atrophy of mammary gland. Moreover, it also induced a significantly increase of the number, duration and frequency of hot flushes in ovariectomized rats (OVX) as compared to normal animals (SHAM). As expected, a 3day consecutive treatment with $\mathrm{E} 2 \mathrm{~V}$ at the optimal dose of $1 \mathrm{mg} / \mathrm{kg}$ and genistein at the dose of $10 \mathrm{mg} / \mathrm{kg}$ significantly reversed atrophy in estrogen target organs (uterine, vagina and mammary gland) and hot flushes observed after ovariectomy. EEP induced a significant increase of uterine wet weight, uterine total protein level, uterine and vaginal epithelial height, mammary gland acini and eosinophil secretion in acini in the bell shaped diagram with the maximum effect at the dose of $150 \mathrm{mg} / \mathrm{kg}$. These results are interesting because the growth-stimulatory effect of EEP at the dose of $150 \mathrm{mg} / \mathrm{kg}$ reported in this work is comparable to results of a well characterized phytoestrogen genistein $(10 \mathrm{mg} / \mathrm{kg})$, suggesting that purification of the active principle of EEP could increase its activity. Additionally the bell shape diagram observed in nearly all assessed parameters suggest a dose-dependent effect of EEP, which is achieved at the optimal dose $(150 \mathrm{mg} / \mathrm{kg})$ and probably decreased due to a phenomenon known as "down regulation" of ERs induced by the high dose. As mentioned above, EEP contains phenolic compounds that are known to stimulate uterine growth, uterine and vaginal epithelial height and mammary gland differentiation in a short-term animal studies [43].

Phenolic compounds contained in EEP might bind to ERs in vivo and modulate the expression of many genes, which can account for the increase in total protein level in uterine, marker of uterine cell proliferation [30, 44]. The increase of protein level in the uterus can induce uterine water imbibition as suggested by some authors $[44,45]$, hence uterine wet weight increases. It is well know that the removal of endogenous estrogen by ovariectomy results in regression of the mammary gland, and that estrogen-like substances reverse this regression [30, 46]. Although the complete pathophysiology of hot flushes is not yet completely understood, their occurrence is assumed to originate in disturbances of the thermo regulatory processes in the hypothalamus, which acts as the body's thermostat [2]. Fluctuation or decline of the free fraction of estrogen levels is associated with the initiation of thermoregulatory dysfunction in women [47]. It was reported that alleviation of hot flushes in women and in rats both require chronic treatment with estrogen (up to a month in women and 3-4 days in rats), suggesting that the action of estrogen is indirect and may involve a cascade in gene expression events including the expression of neurotransmitters and neuropeptides participating in thermoregulation such as serotonin [2]. After 3-day treatment, EEP phenolic compounds significantly decreased the number, the duration and the frequency of hot flushes probably by an ER-dependent mechanism as mentioned above.

In this study, EEP exhibited estrogen-like activity in vivo but seems to be antiestrogenic in vitro. Phytoestrogens is known to have mixed estrogen agonist/antagonist properties which are clinically useful [46]. The fact that 
A

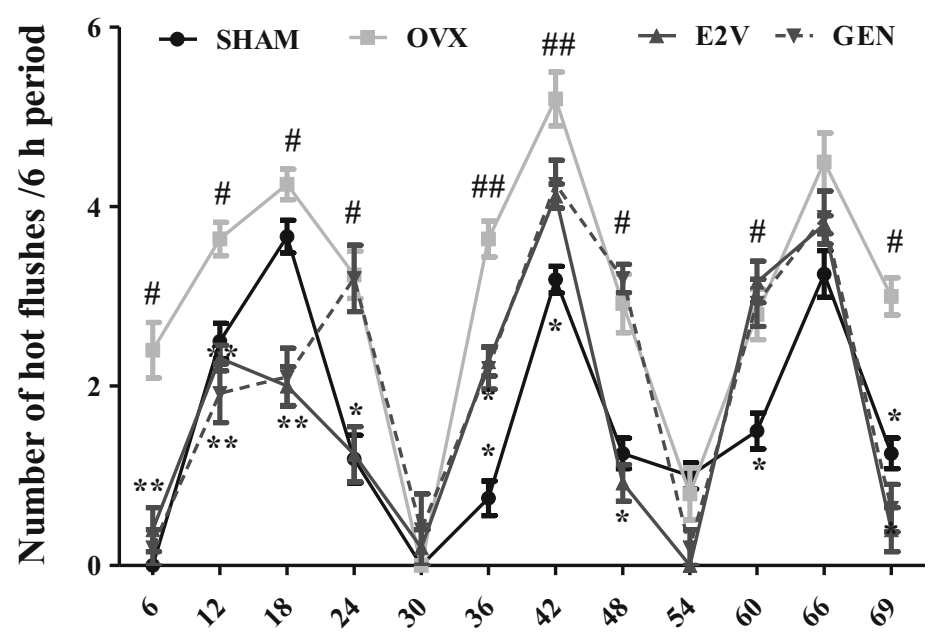

Time (h)

B

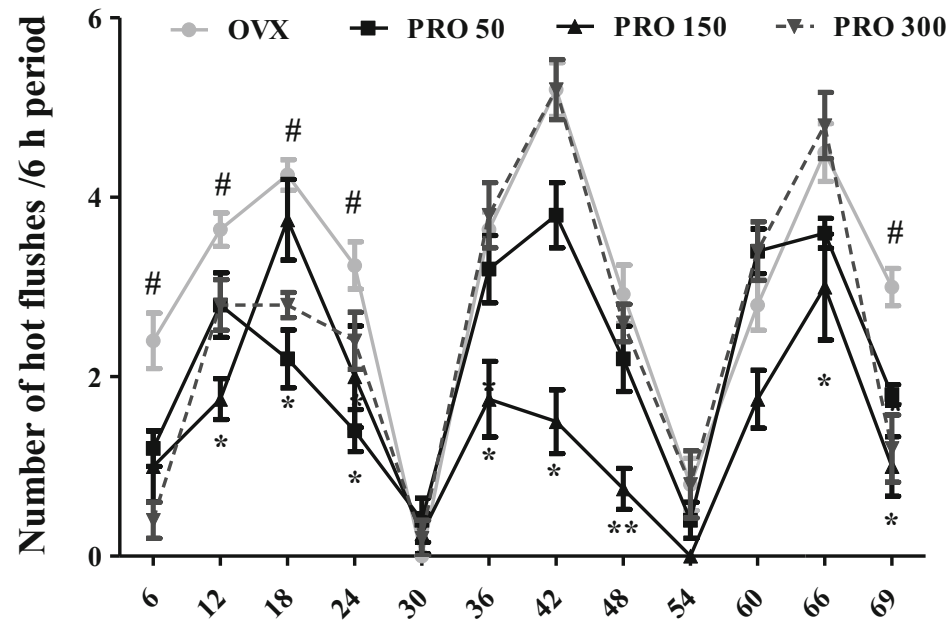

Time (h)

Fig. 9 Effects of a 3-day treatment with standard drugs (a) and EEP (b) on frequency of hot flushes. SHAM = Sham operated rats treated with the vehicle; $\mathrm{OVX}=\mathrm{OVX}$ animals treated with the vehicle; $\mathrm{E} 2 \mathrm{~V}=\mathrm{OVX}$ animals treated with estradiol valerate at $1 \mathrm{mg} / \mathrm{kg} B W ; \mathrm{GEN}=\mathrm{OVX}$ animals treated with genistein at $10 \mathrm{mg} / \mathrm{kg} \mathrm{BW;} \mathrm{PRO}=\mathrm{OVX}$ animals treated with EEP at doses of 50, 150 and $300 \mathrm{mg} / \mathrm{kg} \mathrm{BW}$. * $p<0.05$, ** $p<0.01$ as compared to control. ${ }^{\#} p<0.05,{ }^{\# \#} p<0.01$ as compared to Sham

EEP did not induced reporter gene activation in cell based assay, while it induced an estrogen uterotrophic response in vivo might either be due the high amount of active principles that induced "down regulation" of ERs in HEK293T cells or because active principles of EEP need some enzymatic transformation to be effective, given that in vivo assays take into consideration effects of metabolism, plasma-protein binding and pharmacokinetics [48]. Since a high increase in endometrium height could be a potential risk of endometrial cancer as seen in estrogen replacement therapy [49], the weak effects of EEP in uterine wall can be a safe alternative to
HRT with minimal side effect. Vaginal epithelial proliferation and cornification observed with EEP treatment are desired estrogenic effects, because the lactobacillus use these superficial cells to produce lactic acid, which keeps the vaginal milieu acidic and thus prevent ascending infections [50]; Moreover, vaginal secretive cells will keep the vagina wet, thereby avoiding vaginal dryness. The Combination of therapy with bee venom $(0.2 \mathrm{mg})$ and bee propolis $(0.5 \mathrm{~g})$ was shown to alleviate hot flushes in $85 \%$ of treated menopausal women [51]. These observations concord with part of results obtained with EEP $(150 \mathrm{mg} / \mathrm{kg})$ in hot flushes induced in rats. 


\section{Conclusion}

A universal standardization of propolis would be difficult because propolis biological actions should be linked to its chemical composition and plant sources. Ethanol extracted Cameroonian propolis has now been proven to possess estrogenic-like effects in rat. Knowing that estrogenic properties observed in estrogen-deficient animals following administration of plant preparations are associated to phytoestrogens actions, these results suggest that phenolic compounds detected in Cameroonian propolis may be a potential source of phytoestrogens. This might lead to its possible development as an improved traditional medicine for the alleviation of postmenopausal complaints following further investigation.

\begin{abstract}
Abbreviations
ACN: Acetonitrile; APPI: Atmospheric Pressure Photo Ionisation; BPI: Base peak intensity; CAPE: Caffeic acid phenethyl ester; DMEM: Dulbecco's modified eagle's medium; E2V: Estradiol valerate; EC: Elemental compositions; EEP: Ethanolic extract of Cameroonian propolis; ER: Estrogen receptor; ERE: Estrogen receptor element; ERa: Estrogen receptor alpha; ERß: Estrogen receptor beta; ESI: Electrospray ionization; FA: Formic acid; FBS: Fetal bovine serum; FCS: Fetal calf serum; GC: Gas chromatography; HEK293T: Human Embryonic Kidney 233 T cells; HRMS: High-resolution Mass Spectrometry; HRT: Hormone Replacement Therapy; MS: Mass Spectroscopy; ONPG: Onitrophenyl- $\beta$-galactopyranoside; OVX: Bilaterally ovariectomized rats; PRO: PROMAX-C; RDBeq: Ring Double Bond Equivalent; RPMI: Roswell Park Memorial Institute; Rt: Retention time; Sham: Sham operated animals; SEM: Standard Error of Mean; SRB: Sulforhodamine-B; UPLC: Ultra Performance Liquid Chromatography
\end{abstract}

\section{Acknowledgment}

The authors are really thankful to the German Academic Exchange Service (DAAD) and the Alexander von Humboldt Foundation for support. The authors would also kindly thanks the European Research Institute in Natural Ingredients (ERINI, Grasse, France) for the use of the high resolution mass spectrometer.

\section{Funding}

The authors declare that they have not received any funding for this work.

\section{Availability of data and materials}

The data and materials used in this study are available upon request from the authors.

\section{Authors' contributions}

ZS and ND design the study. ZS and TJ performed the in vivo part of the study. MNCB, ZS and CC performed the in vitro part of the study. TM, NTD and FX performed the phytochemical analysis of the study. FTFN and AM provided propolis sample. All authors have revised and approved the final manuscript.

\section{Competing interests}

The authors declare that they have no competing interests.

\section{Consent for publication}

Not applicable.

\section{Ethics approval and consent to participate}

Housing of animals and all experiments were approved by the Cameroon Institutional National Ethic Committee, which adopted all procedures recommended by the European Union on the protection of animals used for scientific purposes.

\section{Author details}

'Laboratory of Physiology and Natural Products Research, Department of Life and Earth Sciences, Higher Teachers' Training College, University of Maroua,
P.O. Box 55, Maroua, Cameroon. '2Laboratory of Animal Physiology, Department of Animal Biology and Physiology, Faculty of Science, University of Yaounde 1, P.O. Box 812, Yaoundé, Cameroon. ${ }^{3}$ Hudson Institute of Medical Research, 27-31 Wright Street, Clayton, VIC 3168, Australia. ${ }^{4}$ Institute of Chemistry of Nice, Faculty of Science, University Côte d'Azur, UMR CNRS 7272, Valrose Park, Nice, France. ${ }^{5}$ Department of Applied Chemistry, Faculty of Sciences, University of Johannesburg, P.O. Box 17011, Doornfontein 2028, South Africa. ${ }^{6}$ Department of Biological Sciences, Faculty of Science, University of Ngaoundere, P.O. Box 454, Ngaoundere, Cameroon.

Received: 25 June 2016 Accepted: 7 January 2017

Published online: 21 January 2017

\section{References}

1. Dennerstein L. Well-being, symptoms and the menopausal transition. Maturitas. 1996;23:147-57.

2. Freeman EW, Sammel MD, Sanders RJ. Risk of long-term hot flashes after natural menopause: evidence from the penn ovarian aging study cohort. Menopause. 2014;21:924-32.

3. Orleans RJ, Li L, Kim M-J, Guo J, Sobhan M, Soule L, Joffe HV. FDA approval of paroxetine for menopausal hot flushes. N Engl J Med. 2014;370:1777-9.

4. Birge SJ. Is there a role for estrogen replacement therapy in the prevention and treatment of dementia? J Am Geriatr Soc. 1996;44:865-70.

5. Burger H. Hormone replacement therapy in the post-Women's health initiative era. Report of a meeting held in funchal, Madeira. Climacteric. 2003;6:11-36.

6. Rossouw JE, Anderson GL, Prentice RL, LaCroix AZ, Kooperberg C, Stefanick ML. Writing group for the Women's health initiative investigators: risks and benefits of estrogen plus progestin in healthy postmenopausal women: principal results from the Women's health initiative randomized controlled trial. JAMA. 2002;288:321-33.

7. Dietland M-S. Chemical ecology of vertebrates. Cambridge: Cambridge University Press; 2006. p. 287.

8. Pitkin J. Alternative and complementary therapies for menopause. Menop Inter. 2012;18:20-7.

9. Ososki AL, Kennelly EJ. Phyoestrogens: a review of present state of research. Phytother Res. 2003;17:845-69.

10. Djiogue S, Halabalaki M, Njamen D, Kretzschmar G, Lambrinidis G, Hoepping J, Raffaelli FM, Mikros E, Skaltsounis AL, Vollmer G. Erythroidine alkaloids: a novel class of phytoestrogens. Planta Med. 2014;80:861-9.

11. Chearskul S, Kooptiwut S, Chatchawalvanit S, Onreabroi S, Churintrapun M, Saralamp P, Soonthornchareonnon N. Morinda citrifolia has very weak estrogenic activity in vivo. Thai Journal of Physiological Sciences. 2004;17:22-9.

12. Trusheva B, Todorov I, Ninova M, Najdenski H, Daneshmand A, Bankova V. Antibacterial mono- and sesquiterpene esters of benzoic acids from Iranian propolis. Chem Cent J. 2010;4:8. doi:10.1186/1752-153X-4-8.

13. Popova MP, Chinou IB, Marekov IN, Bankova VS. Terpenes with antimicrobial activity from Cretan propolis. Phytochemistry. 2009;70:1262-71.

14. Kalogeropoulos N, Konteles SJ, Troullidou E, Mourtzinos I, Karathanos VT. Chemical composition, antioxidant activity and antimicrobial properties of propolis extracts from Greece and Cyprus. Food Chem. 2009;116:452-61.

15. Song YS, Jin C, Jung KJ, Park E-H. Estrogenic effects of ethanol and ether extracts of propolis. J Ethnopharmacol. 2002;82:89-95.

16. Jung BI, Kim M-S, Kim H-A, Kim D, Yang J, Her S, Song HS. Caffeic acid phenethyl ester, a component of beehive propolis, is a novel selective estrogen receptor modulator. Phytother Res. 2010;24:295-300.

17. Trusheva B, Popova M, Bankova V, Tsvetkova I, Naydensky C, Sabatini AG. A new type of European propolis, containing bioactive labdanes. Riv Ital EPPOS. 2003;36:3-7.

18. Ahn MRS, Kumazawa YUJ, Nakamura M, Matsuka FZ, Nakayama T. Antioxidant activity and constituents of propolis collected in various areas of China. Food Chem. 2007;101:1383-92.

19. Popova M, Silici S, Kaftanoglu O, Bankova V. Antibacterial activity of Turkish propolis and its qualitative and quantitative chemical composition. Phytomedicine. 2005;12:221-8.

20. Castaldo S, Capasso F. Propolis, an old remedy used in modern medicine. Fitoterapia. 2002;73:1-6.

21. Mbawala A, Tchuenguem Fohouo F-N, Djoulde R, Milliere J-B. Spectra of antibacterial activity of propolis (PROMAX-C) samples from two localities of Adamawa province (Cameroon). Res J Microbiol. 2009;4:150-7. 
22. Ingram V, Njikeu J. Sweet, sticky, and sustainable social business. Ecol Soc. 2011;16:37-55.

23. Njintang YN, Tatsadjieu NL, Ngakou A, Danra D, Tchuenguem Fohouo F-N. Antiradical activity and polyphenol content of ethanolic extracts of Propolis. Int J Biosci. 2012;2:56-63.

24. Mbawala A, Roger D, Tchuenguem Fohouo F-N, Milliere JB. In vitro susceptibility of some bacteria strains to ethanol extracts of propolis collected from two different geographic origins in Cameroon. J Food Technol. 2010;8:217-22.

25. Seidel V, Peyfoon E, Watson DG, Fearnley J. Comparative study of the antibacterial activity of propolis from different geographical and climatic zones. Phytother Res. 2008;22:1256-63.

26. Talla E, Dabole B, Taiwe GS, Ngo Bum T, Mbafor JT, Atchade ADT, Malik R, Zulfigar A, Sidiki N, Nguimbou RM, Choudhary MI. Antinociceptive Pentacyclic Triterpenoids from the Cameroonian Brown Propolis. Pharmacologia. 2013;4:218-27.

27. Sakava P, Talla E, Chelea M, Tchinda TA, Zeuko'o ME, Laurent S, Vander EL, Tagatsing FM, Yaya GAJ, Atchade DTA, Mbafor TJ. Pentacyclic triterpenes and crude extracts with antimicrobial activity from Cameroonian brown propolis samples. J Appl Pharm Sci. 2014;4:001-9.

28. Resende FA, De Oliveira APS, De Camargo MS, Vilegas W, Varanda EA. Evaluation of estrogenic potential of flavonoids using a recombinant yeast strain and MCF7/BUS cell proliferation assay. PLoS ONE. 2013:8:74881.

29. Schiliro' T, Gorrasi I, Longo A, Coluccia S, Gilli G. Endocrine disrupting activity in fruits and vegetables evaluated with the E-screen assay in relation to pesticide residues. J Steroid Biochem Mol Biol. 2011;127:139-46.

30. Zingue S, Michel T, Tchatchou J, Magne Nde CB, Winter E, Monchot A, Awounfack CF, Djiogue S, Clyne C, Fernandez X, Creczynski-Pasa TB, Njamen D. Estrogenic effects of Ficus umbellata Vahl. (Moraceae) extracts and their ability to alleviate some menopausal symptoms induced by ovariectomy in Wistar rats. J Ethnopharmacol. 2016;179:332-44.

31. Maswood N, Cosmi S, Alfinito PD, Leventhal L, Deecher DC. The role of the selective serotonin reuptake inhibitor fluoxetine in temperature regulation in ovariectomized Rat models. Neuroendocrinology. 2006;84:330-8.

32. Gonal AG, Bardwill GS, David MM. Determination of serum proteins by the means of biuret reactions. J Biol Chem. 1949;177:751-66.

33. Righi AA, Negri G, Salatino A. Comparative Chemistry of Propolis from Eight Brazilian Localities. J Evid Based Complementary Altern Med. 2013;2013:1-14.

34. Zhanga T, Omara R, Siheria W, Al Mutairia S, Clementsa C, Fearnley J, Edrada-Ebela RA, Watsona D. Chromatographic analysis with different detectors in the chemical characterisation and dereplication of African propolis. Talanta. 2014;120:181-90.

35. Qiao X, Song W, Wang Q, Liu K, Zhang Z-X, Bo T, Li R-Y, Liang L-N, Tzeng YM, Guo D-A, Ye M. Comprehensive chemical analysis of triterpenoids and polysaccharides in the medicinal mushroom Antrodia cinnamomea. RSC Adv. 2015;5:47040-52.

36. Riffault L, Colas C, Destandau E, Pasquier L, André P, Elfakir C. Non-targeted molecular characterisation of a rose flower ethyl acetate extract using UltraHPLC with atmospheric pressure photoionisation and quadrupole time-offlight MS/MS. Phytochem Anal. 2015;26:189-201.

37. Kardar MN, Zhang T, Coxon GD, Watson DG, Fearnley J, Seidel V. Characterisation of triterpenes and new phenolic lipids in Cameroonian propolis. Phytochemistry. 2014;106:156-63.

38. Sanpa S, Popova M, Bankova V, Tunkasiri T, Eitssayeam S, Chantawannakul P. Antibacterial compounds from propolis of tetragonula laeviceps and tetrigona melanoleuca (hymenoptera: apidae) from Thailand. PLoS One. 2015;10:1-11.

39. Li F, Awale S, Zhang H, Tezuka Y, Esumi H, Kadota S. Chemical constituents of propolis from Myanmar and their preferential cytotoxicity against a human pancreatic cancer cell line. J Nat Prod. 2009;72:1283-7.

40. Bankova V. Chemical diversity of propolis and the problem of standardization. J Ethnopharmacol. 2005;100:114-7.

41. Matthews J, Wihlen B, Tujague M, Wan J, Strom A, Gustafsson JÅ. Estrogen receptor (ER) beta modulates ER-alpha-mediated transcriptional activation by altering the recruitment of c-Fos and c-Jun to estrogen-responsive promoters. J Mol Endocrinol. 2006;20:534-43.

42. Okamoto Y, Tobe T, Ueda K, Takada T, Kojima N. Oral administration of Brazilian propolis exerts estrogenic effect in ovariectomized rats. J Toxicol Sci. 2015;40:235-42.

43. Diel P, Geis RB, Caldarelli A, Schmidt S, Leschowsky UL, Voss A, Vollmer G. The differential ability of the phytoestrogen genistein and of estradiol to induce uterine weight and proliferation in the rat is associated with a substance specific modulation of uterine gene expression. Mol Cell Endocrinol. 2004;221:21-32.

44. Hewitt SC, Korach KS. Estrogen receptor knockout mice: roles for estrogen receptors alpha and beta in reproductive tissues. Reproduction. 2003;125: $143-9$.

45. Elbassuoni E, Ragy M, Aziz N. Protective effect of GHRP-6 and estrogen supplementation against some cardiometabolic risk factors in ovariectomized rats. Endocr Regul. 2012;46:73-81.

46. Santell RC, Chang YC, Nair MG, Helferich WG. Dietary genistein exerts estrogenic effects upon the uterus, mammary gland and the hypothalamic/ pituitary axis in rats. J Nutr Educ. 1997;127:263-9.

47. Erlik Y, Meldrum DR, Judd HL. Estrogen levels in postmenopausal women with hot flashes. Obstet Gynecol. 1982;59:403-7.

48. Andersen HR, Andersson AM, Arnold SF, Autrup H, Barfoed M, Beresford NA Bjerregaard P, Christiansen LB, Gissel B, Hummel R, Jorgensen EB, Korsgaard B, Le Guevel R, Leffers H, McLachlan J, Moller A, Nielsen JB, Olea N, OlesKarasko A, Pakdel F, Pedersen KL, Perez P, Skakke-boek NE, Sonnenschein C, Soto AM, Sumpter JP. Comparison of short-term estrogenicity tests for identification ofhormone-disrupting chemicals. Environ Health Persp. 1999; 107:89-108.

49. Ito K. Hormone replacement therapy and cancers: the biological roles of estrogen and progestin in tumor genesis are different between the endometrium and breast. TJEM. 2007;212:1-12.

50. Heinemann C, Reid G. Vaginal microbial diversity among postmenopausal women with and without hormone replacement therapy. Can J Microbiol. 2005;51:777-81.

51. Farid A, Bambi E, Dali E, Essia S. Treatment of menopausal syndrome by beenom and bee propolis (a new modality). Maturitas. 1997;27:201.

52. Almutairi S, Eapen B, Chundi MS, Akhalil A, Siheri W, Clements C, Fearnley J, Watsona DG, Edrada-Ebel R. New anti-trypanosomal active prenylated compounds from African propolis. Phytochem Lett. 2014;10:35-9.

\section{Submit your next manuscript to BioMed Central and we will help you at every step:}

- We accept pre-submission inquiries

- Our selector tool helps you to find the most relevant journal

- We provide round the clock customer support

- Convenient online submission

- Thorough peer review

- Inclusion in PubMed and all major indexing services

- Maximum visibility for your research

Submit your manuscript at www.biomedcentral.com/submit
( Biomed Central 